\title{
Unconventional Fiscal Policy at the Zero Bound*
}

\author{
Isabel Correia $\quad$ Emmanuel Farhi Juan Pablo Nicolini Pedro Teles
}

June 12, 2012

\begin{abstract}
When the zero lower bound on nominal interest rates binds, monetary policy cannot provide appropriate stimulus. We show that, in the standard New Keynesian model, tax policy can deliver such stimulus at no cost and in a time-consistent manner. There is no need to use inefficient policies such as wasteful public spending or future commitments to low interest rates.
\end{abstract}

Key words: Zero Bound; Fiscal policy; Monetary policy; Sticky prices.

JEL classification: E31; E40; E52; E58; E62; E63.

${ }^{*}$ Correia: Banco de Portugal, Universidade Catolica Portuguesa and CEPR. Farhi: Harvard University. Nicolini: FRB of Minneapolis and Universidad Di Tella. Teles: Banco de Portugal, Universidade Catolica Portuguesa and CEPR. This paper circulated with the title Policy at the Zero Bound. We thank Fernando Alvarez, Pierpaolo Benigno, Javier Garcia-Cicco, Gauti Eggertsson, Michel Guillard, Bob Hall, Patrick Kehoe, Narayana Kocherlakota, John Leahy, Greg Mankiw, Kjetil Storesletten, Sam Schulhofer-Wohl, Harald Uhlig, Tao Zha, the editor and three anonymous referees, as well as participants at conferences and seminars where this work was presented. Correia and Teles gratefully acknowledge financial support of FCT. 


\section{Introduction}

Arbitrage between money and bonds requires nominal interest to be positive. This "zero bound" constraint gives rise to a macroeconomic situation known as a liquidity trap. It presents a difficult challenge for stabilization policy.

There is a well developed Keynesian view on the subject. In a liquidity trap, monetary policy is ineffective -increasing the money supply is like "pushing on a string". The standard Keynesian prescription is to use fiscal policy in order to stimulate the economy, in the form of tax cuts or government spending increases. Expansionary fiscal policy is presumed to be especially effective in a liquidity trap due to the lack of eviction effects through higher interest rates. This recommendation has been very influential in shaping policy. Yet its validity can be questioned and refined. Indeed, the absence of microfoundations, lack of dynamics, and neglect of expectations formation, of the basic IS-LM model creates difficulties for normative analysis (how to think about welfare?), as well as for positive analysis (how to think about the adjustment of prices, about the effects of different taxes vs. government expenditures, or about the effects of future policy commitments?).

Recently, a literature has emerged that revisits the Keynesian analysis in the context of explicitly microfounded, dynamic, rational expectations models with nominal rigidities that do not suffer from these shortcomings. There is now an emerging New Keynesian view of liquidity traps. Krugman (1998), and Eggertsson and Woodford (2003), and more recently Werning (2011) have characterized optimal monetary policy at the zero bound. Their work emphasizes the role of policy commitments. They show that it is optimal to commit to keeping the interest rate at zero for longer that under the no-commitment solution. This increases output and inflation both in the present and in the future - optimally trading off the mitigation of a recession in the present and the creation of a boom in the future. This literature has also emphasized the beneficial effects of fiscal policy. For example, Christiano, Eichenbaum, Rebelo (2011), Eggertsson (2009), and Woodford (2010) have shown that government spending multipliers can be very large at the zero bound, and that increasing government spending can be welfare improving.

In this paper we study the liquidity trap in the context of a standard New Keynesian model. We characterize jointly optimal monetary and fiscal policy. Our main result is to demonstrate how distortionary taxes can be used to replicate the effects of negative nominal interest rates and completely circumvent the zero bound problem. We label this scheme unconventional fiscal policy. It involves engineering over time an increasing path for consumption taxes, a decreasing path for labor taxes, coupled with a temporary investment tax credit or a temporary cut in capital income taxes.

Whether or not the first-best allocation can be implemented depends on the set of available instruments, and in particular on the existence of lump sum taxes. In the simple New Keynesian model of Eggertsson (2009), where lump sum taxes are allowed, we show that the first-best allocation can be implemented at the zero bound with unconventional fiscal policy (Section 2). The first-best can also be attained in a model with capital (Section 3), and also in a model with sticky prices and sticky wages (Section 4). In more 
general set ups, full efficiency cannot be attained. That is the case in a Ramsey model in which lump sum taxes cannot be raised. However, as it turns out, the zero bound is not a constraint to that second-best problem: Unconventional fiscal policy can perfectly replicate the effects of negative nominal interest rates at the second-best. This point is more general: The full set of implementable allocations is unrestricted by the zero bound constraint (Section 5). We also quantify the tax policy that would be necessary to avoid a major recession at the zero bound (Section 6).

The intuition why tax policy can neutralize the effects of the zero bound constraint is simple. Suppose real rates ought to be negative. Since the nominal interest rate cannot be negative, the only way to achieve negative real interest rates is to generate inflation. But producer price inflation is costly. Indeed, in the New Keynesian, sticky price, literature, price setting decisions are staggered. Producer price inflation then necessarily leads to dispersion in relative prices - a real economic distortion. Is it possible to achieve negative real interest rates without incurring this economic cost?

It turns out that the prices that matter for intertemporal decisions are consumer prices, which are gross of consumption taxes. The idea is to induce inflation in consumer prices, while keeping producer price inflation at zero. The result is negative real interest rates, and yet the distortions associated with producer price inflation are altogether avoided. This can be achieved by simultaneously adjusting consumption and labor taxes. Imagine first that producer price inflation is zero. Then an increasing path of consumption taxes over time generates inflation in consumer prices. The problem is that this change in consumption taxes introduces undesirable variations in the marginal cost of firms over time - creating incentives for producers to change their prices. This effect must therefore be counteracted with a decreasing path for labor taxes. Overall, this policy achieves a negative interest rate in the consumer price numeraire.

In a model with capital, this policy must be supplemented with a temporary capital subsidy - in the form of a temporary investment tax credit or a temporary cut in capital income taxes. This is because an increasing path of consumption taxes acts as a tax on capital. This tax on capital is undesirable and must be counteracted with a corresponding subsidy in order to adequately channel savings to investment.

As we have described it, unconventional fiscal policy requires permanent tax changes before and after a liquidity trap episode, raising the potential concern that such a scheme can only be applied so many times before running into negative labor income taxes. However we show that these changes can be gradually reversed in good times once the natural interest rate is back to positive territory. It suffices to apply our unconventional fiscal policy in reverse, using a decreasing path for consumption taxes, and increasing path for labor taxes, and an investment tax (a negative investment tax credit), together with a nominal interest rate below the natural interest rate. Such a scheme can also be applied preventively to build a buffer in good times.

Importantly, in our basic setup with lump sum taxes, the optimal policy that we characterize implements the first-best allocation. It is therefore time-consistent. This should be contrasted with the policy recommendations involving future commitments to low interest rates in Krugman (1998) and Eggertsson and 
Woodford (2003). It is also the case that under more reasonable assumptions preventing lump sum taxation, optimal policy is in general time-inconsistent. However, the time-inconsistency that arises is unrelated to the zero bound, since indeed the zero bound does not restrict the second-best problem.

In addition, unconventional fiscal policy is revenue neutral in the following sense. We compare our implementation of the first-best allocation outline above with a fictitious implementation that ignores the zero bound constraints and uses time-varying nominal interest rates (allowing for negative nominal interest rates) but constant tax policy. We show that under these two schemes, the net present value of lump sum taxes is the same. In this sense, unconventional fiscal policy is revenue neutral. More generally, there are many ways to implement the first-best allocations by jointly using nominal interest rates and taxes away from the zero bound. All these implementations feature the same net present value of lump sum taxes.

To have a sense of the magnitudes that the changes in taxes involve, in Section 6, we take the simpler model in Christiano et al. (2011), consider the same shock to the rate of time preference, calibrated to generate a recession at the liquidity trap, and compute the allocations that would have occurred with a Taylor rule allowing for negative nominal interest rates. We then compute the taxes that would support that same allocation with zero interest rates. The rate of time preference remains high for ten quarters, corresponding to a natural rate of interest - the one that would occur under flexible prices and wages - of minus $4 \% .{ }^{1}$ While the natural rate of interest is negative, the economy is, by definition, in a liquidity trap. In the model with sticky prices, the economy would stay at the zero bound for five quarters. Consumption taxes starting at the steady state level of $5 \%$ would increase to $14 \%$ over that period. Labor income taxes would decrease gradually from the steady state level of $28 \%$ to $21 \%$. The investment subsidy would jump initially to $9 \%$ and come down to zero over the five quarters.

The tax rates stabilize at the new levels after period six. Successive liquidity trap episodes of this type would eventually require labor income taxes to be negative. To avoid this, the tax policies can be reversed after the liquidity trap is over, i.e. after ten quarters. The nominal rate would remain at the zero bound for another eight quarters and the tax rates would return to their steady state levels.

The welfare gains from replicating the allocations with a nontruncated Taylor rule are considerable. But they are higher if the allocation that is implemented is the one that would occur if prices and wages were flexible, which can also be attained here. The taxes that would support that allocation would have the consumption tax rise from $5 \%$ to $10 \%$ gradually over the ten quarters that the liquidity trap lasts. The labor income tax would drop from $28 \%$ to $24.5 \%$ over the same period, and the investment tax credit would jump to $4 \%$ and come back to zero at the end of the liquidity trap.

Literature review. There is a vast literature on the zero bound in New Keynesian models. This literature has focused both on fiscal policy and on monetary policy. Some papers also consider monetary and fiscal policy jointly. The general conclusion is that the zero bound is a serious challenge to policy, justifying the

\footnotetext{
${ }^{1}$ The steady state level is assumed to be the one corresponding to a real rate of plus $4 \%$.
} 
use of inefficient policies.

The earlier work on the implications of the zero bound for monetary and fiscal policy was motivated by the prolonged recession in Japan where overnight rates have been close to zero for the last fifteen years, as well as by the low targets for the Fed funds rate in the US in 2003 and $2004 .^{2}$ Krugman (1998), Eggertsson and Woodford (2003 and 2004a) show that there may be downturns that could, and should, be avoided if it was not for the zero bound. They also show how monetary policy can be adjusted so that the costs of those downturns may be reduced. In particular they propose policies that keep the interest rate for a longer period at zero in order to generate inflation.

Eggertsson and Woodford (2004b) consider both monetary and fiscal policy in a Ramsey taxation model with no capital, with consumption taxes assuming that the prices are sticky inclusive of those taxes. Those taxes can be used to partially offset the effects of the zero bound, and additional taxes, such as labor income taxes, are redundant. They also point out that if there were to be two consumption taxes, such that prices are set after one and before the other, then it would be possible to implement the same allocation as if the zero bound did not bind. They find the use of those taxes to be unrealistic. ${ }^{3}$

There is also recent work on public spending multipliers, showing that these can be very large at the zero bound (see Christiano et al. (2011), Eggertsson (2009), Woodford (2010), Mertens and Ravn (2010 ${ }^{4}$ ). Eggertsson (2009) also considers different alternative taxes and assesses which one is the most desirable to deal with the zero bound. The zero bound is also a key component in the numerical work presented in the evaluation of the American Recovery and Reinvestment Plan by Romer and Bernstein (2009). It is also a main concern in Blanchard, Dell'Ariccia and Mauro (2010) who argue for a better integration between monetary and fiscal policy.

With a different focus, Correia, Nicolini, and Teles (2008) show that fiscal policy can be used to neutralize the effects of price stickiness. They consider an optimal Ramsey taxation model without capital and with a monetary distortion, similar to the one in Lucas and Stokey (1983) and Chari, Christiano and Kehoe (1991), but with sticky prices. They show that under sticky prices it is possible to implement the same allocations as under flexible prices, and that it is optimal to do so. Since the zero bound is the optimal policy under flexible prices, it must also be the optimal one under sticky prices ${ }^{5}$.

These results and the pressing relevance of the policy question were the motivation for this work.

\footnotetext{
${ }^{2}$ In 2003 and 2004, the Fed funds rate fell down to 1\%, and remained there for more than year.

${ }^{3}$ The justification for lack of realism is (i) that most countries do not have US sales-type taxes (even if very high pass through of VAT taxes to prices has been found in the data) and (ii) that a nonnegativity constraint on the taxes would be violated (which we show can be partly dealt with).

${ }^{4}$ Mertens and Ravn show that multipliers can be low if the economy is close to an alternative, liquidity trap, steady state.

${ }^{5}$ In a model with cash and credit goods, additional conditions are needed for that to be the case. But, the optimality of the Friedman rule is a robust result in other monetary models with flexible prices.
} 


\section{$2 \quad$ A simple model}

We use a standard new-Keynesian model, similar to the one analyzed by Eggertsson and Woodford (2003) and (2004b), and Eggertsson (2009). The economy is cashless.

The uncertainty in period $t \geq 0$ is described by the random variable $s_{t} \in S_{t}$, where $S_{t}$ is the set of possible events at $t$, and the history of its realizations up to period $t$ is denoted by $s^{t} \in S^{t}$. For simplicity we index by $t$ the variables that are functions of $s^{t}$.

We assume that there is a representative household with preferences described over aggregate consumption $C_{t}$ and leisure $L_{t}$,

$$
E_{0} \sum_{t=0}^{\infty} \beta^{t} u\left(C_{t}, L_{t}, \xi_{t}\right)
$$

with

$$
C_{t}=\left[\int_{0}^{1} c_{i t}^{\frac{\theta-1}{\theta}} d i\right]^{\frac{\theta}{\theta-1}}
$$

where $c_{i t}$ is private consumption of variety $i \in[0,1]$, and $\xi_{t}$ is a preference shock. $\theta>1$ is the elasticity of substitution between varieties.

Aggregate government consumption $G_{t}$ is exogenous. It is also a Dixit-Stiglitz aggregator of public consumption of different varieties $g_{i t}$,

$$
G_{t}=\left[\int_{0}^{1} g_{i t}^{\frac{\theta-1}{\theta}} d i\right]^{\frac{\theta}{\theta-1}}
$$

The production function of each good $i$, uses labor, $n_{i t}$, according to

$$
c_{i t}+g_{i t}=A_{t} n_{i t},
$$

where $A_{t}$ is an aggregate productivity shock. Total labor $N_{t}$ is

$$
N_{t}=\int_{0}^{1} n_{i t} d i
$$

and, because we normalize total time endowment to one,

$$
N_{t}=1-L_{t}
$$

\subsection{Government}

As is standard in the new-Keynesian literature, we allow for lump-sum taxes $T_{t}$, which is a residual variable that adjusts so that the government budget constraint is satisfied. There are also taxes on consumption $\tau_{t}^{c}$, labor income $\tau_{t}^{n}$, and profits $\tau_{t}^{d}$.

The government minimizes the expenditure on the individual goods, given $G_{t}$. If we let

$$
P_{t} \equiv\left[\int_{0}^{1} p_{i t}{ }^{1-\theta} d i\right]^{\frac{1}{1-\theta}},
$$

where $p_{i t}$ is the price of variety $i$, then, the minimization of expenditure on the individual goods, implies

$$
\frac{g_{i t}}{G_{t}}=\left(\frac{p_{i t}}{P_{t}}\right)^{-\theta}
$$




\subsection{Households}

The representative household also minimizes spending on aggregate $C_{t}$, by choosing the consumption of different varieties according to

$$
\frac{c_{i t}}{C_{t}}=\left(\frac{p_{i t}}{P_{t}}\right)^{-\theta}
$$

The budget constraint can then be written in terms of the aggregates as

$$
\begin{aligned}
\frac{1}{1+i_{t}} \bar{B}_{t}+E_{t} Q_{t, t+1} B_{t, t+1} & =\bar{B}_{t-1}+B_{t-1, t}+\left(1-\tau_{t}^{n}\right) W_{t} N_{t} \\
& +\left(1-\tau_{t}^{d}\right) \Pi_{t}-\left(1+\tau_{t}^{c}\right) P_{t} C_{t}-T_{t}, t \geq 0
\end{aligned}
$$

together with a no-Ponzi games condition. $B_{t, t+1}$ represent the quantity of state contingent bonds that pay one unit of money at time $t+1$, in state $s^{t+1}$ and $\bar{B}_{t}$ are risk free nominal bonds paying one unit of money at $t+1$. The price of the state contingent bonds, normalized by the probability of occurrence of the state

at $t+1$, is $Q_{t, t+1}$. Consequently $E_{t} Q_{t, t+1}=\frac{1}{1+i_{t}}$ is the price of the riskless bond, where $1+i_{t}$ is the gross nominal interest rate. The nominal wage is $W_{t}$ and $\Pi_{t}=\int_{0}^{1} \Pi_{i t} d i$ are total profits.

The first order conditions of the household problem that maximizes utility (1) subject to the budget constraint (10) with respect to the aggregates are

$$
\begin{gathered}
\frac{u_{C}\left(C_{t}, L_{t}, \xi_{t}\right)}{u_{L}\left(C_{t}, L_{t}, \xi_{t}\right)}=\frac{1+\tau_{t}^{c}}{1-\tau_{t}^{n}} \frac{P_{t}}{W_{t}}, \\
Q_{t, t+1}=\frac{\beta u_{C}\left(C_{t+1}, L_{t+1}, \xi_{t+1}\right)}{u_{C}\left(C_{t}, L_{t}, \xi_{t}\right)} \frac{\left(1+\tau_{t}^{c}\right) P_{t}}{\left(1+\tau_{t+1}^{c}\right) P_{t+1}},
\end{gathered}
$$

and

$$
\frac{u_{C}\left(C_{t}, L_{t}, \xi_{t}\right)}{\left(1+\tau_{t}^{c}\right) P_{t}}=\left(1+i_{t}\right) E_{t} \frac{\beta u_{C}\left(C_{t+1}, L_{t+1}, \xi_{t+1}\right)}{\left(1+\tau_{t+1}^{c}\right) P_{t+1}}
$$

\section{$2.3 \quad$ Firms}

Each variety is produced by a monopolist. Prices are set as in Calvo (1983). Every period, a firm is able to revise the price with probability $1-\alpha$. The lottery that assigns rights to change prices is i.i.d. over time and across firms. Since there is a continuum of firms, $1-\alpha$ is also the share of firms that are able to revise prices. Those firms choose the price $p_{t}$ to maximize profits net of taxes,

$$
E_{t} \sum_{j=0}^{\infty} \alpha^{j} Q_{t, t+j}\left(1-\tau_{t+j}^{d}\right)\left[p_{t} y_{t+j}-W_{t+j} n_{t+j}\right]
$$

where output $y_{t+j}=c_{t+j}+g_{t+j}$ must satisfy the technology constraint (4) and the demand function

$$
y_{t+j}=\left(\frac{p_{t}}{P_{t+j}}\right)^{-\theta} Y_{t+j}
$$

obtained from (8) and (9), where $Y_{t+j}=C_{t+j}+G_{t+j} \cdot Q_{t, t+j}$ is the nominal price at $t$ of one unit of money at a particular state in period $t+j$. 
The optimal price set by these firms is ${ }^{6}$

$$
p_{t}=\frac{\theta}{\theta-1} E_{t} \sum_{j=0}^{\infty} \eta_{t, j} \frac{W_{t+j}}{A_{t+j}}
$$

where

$$
\eta_{t, j}=\frac{(\alpha \beta)^{j} \frac{\left(1-\tau_{t+j}^{d}\right) u_{C}(t+j)}{\left(1+\tau_{t+j}^{C}\right)}\left(P_{t+j}\right)^{\theta-1} Y_{t+j}}{E_{t} \sum_{j=0}^{\infty}(\alpha \beta)^{j} \frac{\left(1-\tau_{t+j}^{d}\right) u_{C}(t+j)}{\left(1+\tau_{t+j}^{C}\right)}\left(P_{t+j}\right)^{\theta-1} Y_{t+j}} .
$$

The price level in (7) can be written as

$$
P_{t}=\left[(1-\alpha) p_{t}^{1-\theta}+\alpha P_{t-1}^{1-\theta}\right]^{\frac{1}{1-\theta}}
$$

\subsection{Equilibria}

Using the demand functions (8) and (9), it follows from (4) and (5) that

$$
C_{t}+G_{t}=\left[\int_{0}^{1}\left(\frac{p_{i t}}{P_{t}}\right)^{-\theta} d i\right]^{-1} A_{t} N_{t} .
$$

From the expression for the price level, (7), it follows that $\int_{0}^{1}\left(\frac{p_{i t}}{P_{t}}\right)^{-\theta} d i$ is greater than or equal to one. It is strictly greater than one when there is price dispersion, $\frac{p_{i t}}{P_{t}} \neq 1$ for a set of positive measure of firms. This means that for a given level of total time working $N_{t}$, the resources available for consumption are maximized when there is no price dispersion.

An equilibrium for $\left\{C_{t}, L_{t}, N_{t}\right\},\left\{p_{t}, P_{t}, W_{t}\right\}$, and $\left\{i_{t} \geq 0, \tau_{t}^{c}, \tau_{t}^{n}, \tau_{t}^{d}\right\}$ is characterized by conditions (11), (13), (14), (15), (16), (6), and (17) rewritten as

$$
C_{t}+G_{t}=\left[\sum_{j=0}^{t+1} \varpi_{j}\left(\frac{p_{t-j}}{P_{t}}\right)^{-\theta}\right]^{-1} A_{t} N_{t},
$$

in which $\varpi_{j}$ is the share of firms that have set prices $j$ periods before, $\varpi_{j}=(\alpha)^{j}(1-\alpha), j=0,1,2, \ldots, t$, and $\varpi_{t+1}=(\alpha)^{t+1}$, which is the share of firms that have never set prices so far. We assume that they all charge an exogenous price $p_{-1} \cdot{ }^{7}$

\subsection{First-best allocation}

The first-best allocation is the one that maximizes utility (1) subject to the technology constraints (2), (3), (4), (5) and (6), above. From (4) and (5), it follows that the marginal rate of transformation between any

\footnotetext{
${ }^{6}$ Notice that we are assuming that firms set prices before consumption taxes. This is an important assumption. We base this on the extensive evidence of very high pass-through of consumption taxes even in the cases in which the usual practice is to quote after tax prices, as is the case for the value added tax in Europe.

${ }^{7}$ We do not need to keep track of the budget constraints, since lump sum taxes adjust to satisfy the budget.
} 
two varieties is equal to one. Because the marginal rate of substitution is $\left(\frac{c_{i t}}{c_{j t}}\right)^{-\frac{1}{\theta}}$, it must be that the first-best allocation satisfies

$$
c_{i t}=C_{t}, \text { all } i, t
$$

A similar argument applies to public consumption of the different varieties, so that

$$
g_{i t}=G_{t} \text {, all } i, t
$$

The efficiency conditions for the aggregates $\left(C_{t}, L_{t}\right)$ are fully determined by:

$$
\frac{u_{C}\left(C_{t}, L_{t}, \xi_{t}\right)}{u_{L}\left(C_{t}, L_{t}, \xi_{t}\right)}=\frac{1}{A_{t}}
$$

and

$$
C_{t}+G_{t}=A_{t}\left(1-L_{t}\right)
$$

We now show that there are policies and prices that support the first-best allocation, both away from and at the zero bound. We do this by showing that there are policies and prices satisfying all the equilibrium conditions, above, for the first-best allocation, taking into account the zero bound constraint on the nominal interest rate.

\subsection{Optimal policy}

In the simple model that we consider in this section, as well as in Sections 3 and 4, profit taxes are irrelevant: The first-best allocation can be implemented in the exact same way irrespective of profit taxes $\left\{\tau_{t}^{d}\right\}$, which only impact the sequence of lump sum taxes $T_{t}$. Instead, the profit tax will be useful to show the more general results in Section $5^{8}$. Until then, to fix ideas, and without any loss of generality, we can imagine that profits are fully taxed, in the sense that we consider the limiting case in which the tax rate converges to one.

Policy away from the zero bound. Away from the zero bound, monetary policy can implement the first-best allocation with constant taxes on consumption $\tau^{c}$ and labor $\tau^{n}$. In order for private and public consumption to be the same across varieties, all firms must charge the same price (conditions (8) and (9)). That can only be the case if firms start at time zero with a common price, $p_{-1},{ }^{9}$ as we assume, and if firms that can subsequently change prices choose that common price, so that the price level is constant, $p_{t}=P_{t}=p_{-1}$. Every implementation of the first-best allocation must have this feature because price setting decisions are staggered, so that inflation comes at the cost of dispersion in relative prices - a production distortion.

It follows that the aggregate resource constraint (18) coincides with the one at the first-best (20). Calvo's price setting condition (14) can be written in recursive form as

$$
p_{t}=\eta_{t, 0} \frac{\theta}{(\theta-1)} \frac{W_{t}}{A_{t}}+\left(1-\eta_{t, 0}\right) E_{t} p_{t+1} .
$$

\footnotetext{
${ }^{8}$ We thank a referee for pointing this out.

${ }^{9}$ This is the standard assumption in the literature. Yun (2005) is an exception. We relax this assumption in the appendix.
} 
So, when $p_{t}=p_{-1}$, it must be that

$$
p_{t}=p_{-1}=P=\frac{\theta}{(\theta-1)} \frac{W_{t}}{A_{t}},
$$

as under flexible prices. Thus, the nominal wage must move with productivity so as to maintain the nominal marginal cost constant.

From (13), with constant price level and consumption taxes, we have

$$
u_{C}\left(C_{t}, N_{t}, \xi_{t}\right)=\left(1+i_{t}\right) E_{t}\left[\beta u_{C}\left(C_{t+1}, N_{t+1}, \xi_{t+1}\right)\right]
$$

so the nominal interest rate must equal the natural rate of interest - the real interest rate that prevails at the efficient allocation.

From (11) and (21), it must be that

$$
\frac{u_{C}\left(C_{t}, N_{t}, \xi_{t}\right)}{u_{L}\left(C_{t}, N_{t}, \xi_{t}\right)}=\frac{1+\tau_{t}^{c}}{1-\tau_{t}^{n}} \frac{\theta}{\theta-1} \frac{1}{A_{t}} .
$$

In order to offset the distortion arising from monopoly pricing and verifying the efficiency condition (19), the taxes must be such that $\frac{\theta}{\theta-1} \frac{1+\tau_{t}^{c}}{1-\tau_{t}^{n}}=1$. One possibility is to set consumption taxes to zero, $\tau^{c}=0$. The resulting labor subsidy, $\tau^{n}=\frac{-1}{\theta-1}$, is constant over time.

As long as the natural rate of interest is nonnegative, $u_{C}\left(C_{t}, N_{t}, \xi_{t}\right) \geq E_{t}\left[\beta u_{C}\left(C_{t+1}, N_{t+1}, \xi_{t+1}\right)\right]$, which would be the case in normal times, monetary policy achieves perfect economic stabilization. We now look at the more interesting case where the natural rate of interest is negative.

Policy at the zero bound. We have seen that, in order to implement the first-best allocation with constant taxes, the nominal interest rate must equal the natural rate of interest, and prices must be constant. This implementation breaks down when the natural rate of interest turns negative, because of the zero lower bound. With constant taxes, this failure is unavoidable and optimal monetary policy can only achieve a second-best allocation. Here we explain how flexible taxes can be used to completely circumvent the zero lower bound and implement the first-best allocation.

The intertemporal condition (13) can be satisfied with zero nominal interest rates $i_{t}=0$ and constant prices with the appropriate choice of consumption taxes over time:

$$
\frac{u_{C}\left(C_{t}, L_{t}, \xi_{t}\right)}{\left(1+\tau_{t}^{c}\right)}=E_{t} \frac{\beta u_{C}\left(C_{t+1}, L_{t+1}, \xi_{t+1}\right)}{\left(1+\tau_{t+1}^{c}\right)}
$$

The labor income tax must be chosen such that $\frac{\theta}{\theta-1} \frac{1+\tau_{t}^{c}}{1-\tau_{t}^{n}}=1$ to eliminate the monopolistic distortion in (22). Note that the taxes that implement the first-best at the zero bound do not have to respond to contemporaneous information. Consumption and labor income taxes can be predetermined. Finally, the nominal wage moves with productivity according to (21).

Hence, as long as consumption and labor income taxes are flexible instruments, the first-best can be achieved, and the zero bound is not a constraint to policy. In the rest of the paper, we will use the term unconventional fiscal policy to refer to the combination of taxes that circumvents the zero bound. 
In order to build intuition for the required behavior of taxes, we now consider a special case of the model - the same considered by Eggertsson (2009) and Christiano et al. (2011) - and describe optimal tax policy following a shock that lowers the natural rate of interest to the point where the zero bound constraint would be binding.

\subsection{Illustration: using fiscal policy to avoid a recession}

As in Eggertsson (2009) and Christiano et al. (2011) we consider the particular preferences

$$
u\left(C_{t}, L_{t}, \xi_{t}\right)=u\left(C_{t}, L_{t}\right) \xi_{t}
$$

In this way, the preference shock does not affect the marginal rate of substitution between consumption and leisure. It does, however, affect the marginal rate of substitution between consumption at time $t$ and consumption at time $t+1$. We also assume that $G_{t}=G, A_{t}=1$, so that the only shock is the preference shock.

Note that in this case, the conditions (19) and (20) imply that the first-best allocation is unaffected by the preference shock, and is constant.

Let us consider a particular example, a deterministic version of an example in Eggertsson (2009) and Christiano et al. (2011). In their models, it is this shock - interacting with the zero bound - that generates a potentially big recession. Assume that $\xi_{t}$ evolves exogenously according to $\xi_{t} / \xi_{t+1}<\beta$ for $t=0,1, . ., T-1$, and $\xi_{t} / \xi_{t+1}=1$ for $t \geq T$. The natural rate of interest is $\xi_{t} / \beta \xi_{t+1}-1<0$ if $t \leq T-1$ and $\beta^{-1}-1>0$ for $t \geq T$.

We set the nominal interest rate to $i_{t}=0$ for $t \leq T-1$ and $i_{t}=\beta^{-1}-1$ for $t \geq T$. We set the path of consumption taxes according to

$$
\frac{1+\tau_{t+1}^{c}}{1+\tau_{t}^{c}}=\beta \frac{\xi_{t+1}}{\xi_{t}}, \text { for } t=0,1,2, . ., T-1,
$$

and we set labor taxes so that $\frac{1+\tau_{t}^{c}}{1-\tau_{t}^{n}} \frac{\theta}{\theta-1}=1$, for all $t$. For $t \geq T$, the tax rates are constant.

Given an initial consumption tax, $\tau_{0}^{c}$, the equations above completely determine the paths of consumption and labor taxes. Consumption taxes increase over time for $t \leq T-1$ and then stabilize at some constant level for $t \geq T$. Labor taxes follow the opposite pattern: they decrease over time for $t \leq T-1$ and then stabilize at a constant level for $t \geq T$.

This policy resembles the sales tax holiday proposal by Hall and Woodward ${ }^{10}$ at the end of 2008 and Feldstein ${ }^{11}$ in 2003 addressing the Japanese stagnation in the nineties. Our model formalizes these proposals and highlights the way other taxes must be jointly used in order to avoid distorting other margins.

\footnotetext{
${ }^{10}$ An article by Justin Lahart in the Wall Street Journal, January 5, 2009, "State Sales-Tax Cuts: Get Another Look", comments on the proposals of Hall and Woodward in their blog. See also the speech by Narayana Kocherlakota, President of the Minneapolis Fed, "Monetary Policy Actions and Fiscal Policy Substitutes," November 18, 2010.

11 "The Japanese government could announce that it will raise the current 5 percent value added tax by 1 percent per quarter and simultaneously reduce the income tax rates to keep revenue unchanged, continuing this for several years until the VAT reaches 20 percent." Feldstein (2003).
} 
We now make explicit some important properties of the optimal policy solution that we have characterized. We show that it has two important desirable features. First, it is time-consistent. Second, it is revenueneutral. These properties enhance its practical applicability.

\subsection{Revenue neutrality}

Unconventional fiscal policy is revenue neutral in a sense that we, now, make precise. Notice that away from the zero bound, when the natural rate of interest is positive, policy can be conducted with variable nominal interest rates and constant taxes, or with variable taxes and constant interest rates, or a combination of both. All these implementations share the same present value of lump sum taxes. To see this, notice that the present value budget constraint of the household, with $\tau_{t}^{d}=1$, can be written as

$$
E_{0} \sum_{t=0}^{\infty} Q_{0, t}\left[\left(1+\tau_{t}^{c}\right) P_{t} C_{t}-\left(1-\tau_{t}^{n}\right) W_{t} N_{t}+T_{t}\right]=\bar{B}_{0}+B_{-1,0}
$$

Rearranging terms, and replacing prices and taxes from the household marginal conditions (11) and (12), we obtain

$$
E_{0} \sum_{t=0}^{\infty} Q_{0, t} T_{t}=\bar{B}_{0}+B_{-1,0}-\frac{P_{0}\left(1+\tau_{0}^{c}\right)}{u_{C}(0)} E_{0} \sum_{t=0}^{\infty} \beta^{t}\left[u_{C}(t) C_{t}-u_{L}(t) N_{t}\right] .
$$

At the first-best, $P_{0}=p_{-1}$, and $\tau_{0}^{c}$ is unrestricted by the particular implementation. It follows that the present value of lump sum taxes $E_{0} \sum_{t=0}^{\infty} Q_{0, t} T_{t}$ does not depend on the implementation of the first-best allocation. It is in this sense that unconventional fiscal policy is revenue neutral.

At the zero bound, we can only compare the implementation with unconventional fiscal policy with a fictitious implementation that allows for negative nominal interest rates. Those alternative implementations also deliver the same present value of lump sum taxes.

\subsection{Time-consistency}

Because unconventional fiscal policy implements the first-best allocation, it is time-consistent. If a future planner were given an opportunity to revise this policy in the future, it would choose not to do so. This should be contrasted with the policy recommendations involving future commitments to low interest rates in Krugman (1998) and Eggertsson and Woodford (2003 and 2004a). These policies involve commitments to "being irresponsible" in the future by keeping the nominal interest rate below the natural rate of interest even when the latter turns back positive. When the future comes, a planner is tempted to renege on these commitments and raise interest rates as soon at the natural rate of interest turns positive.

This represents an additional advantage of unconventional fiscal policy. Not only does it deliver a better allocation (the first-best one), it also has the benefit of not requiring costly commitments that might be difficult to make credible. 


\section{A model with capital}

The model can easily be extended to allow for capital accumulation. However, time varying consumption taxes of the type we propose to circumvent the zero bound, will distort capital accumulation. To undo this distortion and achieve the first-best, policy must include taxes that directly affect the marginal decision to accumulate capital. We consider taxes that exist in the current tax codes, such as a capital income tax and an investment tax credit. As we show below, while either one suffices for the theoretical results, they do have different quantitative implications.

We assume that total investment, $I_{t}$, is also an aggregate of the individual varieties,

$$
I_{t}=\left[\int_{0}^{1} i_{i t}^{\frac{\theta-1}{\theta}} d i\right]^{\frac{\theta}{\theta-1}} .
$$

Aggregate investment increases the capital stock according to

$$
K_{t+1}=(1-\delta) K_{t}+I_{t}
$$

Capital is accumulated by the representative household, that minimizes the expenditure on the individual investment goods by choosing

$$
\frac{i_{i t}}{I_{t}}=\left(\frac{p_{i t}}{P_{t}}\right)^{-\theta}
$$

We assume that the investment tax credit, $s_{t}^{I}$, applies to the gross investment made by the household, $P_{t}\left[K_{t+1}-(1-\delta) K_{t}\right]$. In addition, the tax $\tau_{t}^{k}$ is levied on capital income with an allowance for depreciation, $\left(U_{t} K_{t}-\delta P_{t} K_{t}\right)$, where $U_{t}$ is the rental cost of capital.

The period-by period budget constraint can, thus, be written as

$$
\begin{aligned}
& \frac{1}{1+i_{t}} \bar{B}_{t+1}+E_{t} Q_{t, t+1} B_{t, t+1}+\left(1-s_{t}^{I}\right) P_{t} K_{t+1} \\
\leq & \bar{B}_{t}+B_{t-1, t}+\left(1-s_{t}^{I}\right)(1-\delta) P_{t} K_{t}+ \\
& \left(1-\tau_{t}^{k}\right) U_{t} K_{t}+\tau_{t}^{k} \delta P_{t} K_{t}+\left(1-\tau_{t}^{n}\right) W_{t} N_{t}+\left(1-\tau_{t}^{d}\right) \Pi_{t}-\left(1+\tau_{t}^{c}\right) P_{t} C_{t}-T_{t} .
\end{aligned}
$$

The marginal condition for capital accumulation by households is

$$
P_{t}=E_{t} Q_{t, t+1}\left[\frac{\left(1-s_{t+1}^{I}\right)}{\left(1-s_{t}^{I}\right)}(1-\delta) P_{t+1}+\frac{\left(1-\tau_{t+1}^{k}\right) U_{t+1}+\tau_{t+1}^{k} \delta P_{t+1}}{\left(1-s_{t}^{I}\right)}\right], t \geq 0,
$$

which, using (12), can be written as

$$
\frac{u_{C}\left(C_{t}, L_{t}, \xi_{t}\right)}{1+\tau_{t}^{c}}=E_{t} \frac{\beta u_{C}\left(C_{t+1}, L_{t+1}, \xi_{t+1}\right)}{1+\tau_{t+1}^{c}}\left[\frac{1-s_{t+1}^{I}}{1-s_{t}^{I}}(1-\delta)+\frac{\left(1-\tau_{t+1}^{k}\right) \frac{U_{t+1}}{P_{t+1}}+\tau_{t+1}^{k} \delta}{1-s_{t}^{I}}\right] .
$$

A constant investment tax credit is equivalent to a constant subsidy to capital income gross of depreciation. However, a variable investment tax credit can have a larger impact on the return from capital accumulation. For instance, note that if the subsidy only lasts for one period -period $t$-, so that $s_{t+1}^{I}=0$, the direct impact of the subsidy $s_{t}^{I}$ also raises the value of the undepreciated capital. 
The production of each good $i, y_{i t}$, uses labor, $n_{i t}$, and capital, $k_{i t}$, and is given by

$$
y_{i t}=A_{t} F\left(k_{i t}, n_{i t}\right)
$$

where $A_{t}$ is an aggregate productivity shock and $F$ is constant returns to scale. The demand for each variety is

$$
\frac{y_{i t}}{Y_{t}}=\left(\frac{p_{i t}}{P_{t}}\right)^{-\theta}
$$

obtained from (8), (9), and (27), where $y_{i t}=c_{i t}+i_{i t}+g_{i t}$, and $Y_{t}=C_{t}+I_{t}+G_{t}$.

Each firm chooses the same capital-labor ratio, $\frac{k_{i t}}{n_{i t}}=\frac{K_{t}}{N_{t}}$ according to

$$
\frac{U_{t}}{W_{t}}=\frac{F_{k}\left(\frac{K_{t}}{N_{t}}\right)}{F_{n}\left(\frac{K_{t}}{N_{t}}\right)}
$$

The corresponding cost function is $C\left(y_{i t} ; U_{t}, W_{t}\right)=\frac{U_{t}}{F_{k}\left(\frac{K_{t}}{N_{t}}\right)} y_{i t}=\frac{W_{t}}{F_{n}\left(\frac{K_{t}}{N_{t}}\right)} y_{i t}$, so that marginal cost is a function of the aggregates only. The optimal price set by the firms that are able to reset prices is

$$
p_{t}=\frac{\theta}{\theta-1} E_{t} \sum_{j=0}^{\infty} \eta_{t, j} \frac{W_{t+j}}{A_{t+j} F_{n}\left(\frac{K_{t+j}}{N_{t+j}}\right)},
$$

where $\eta_{t, j}$ are the same as in the model without capital, (15).

Market clearing for each variety implies that

$$
c_{i t}+g_{i t}+i_{i t}=A_{t} F\left(n_{i t}, k_{i t}\right)
$$

while for capital and labor it must be that

$$
K_{t}=\int_{0}^{1} k_{i t} d i
$$

and (5) hold, respectively.

Using the demand functions (8),(9), and (27), as well as (5), (26), (35), and (36), it follows that

$$
C_{t}+G_{t}+K_{t+1}-(1-\delta) K_{t}=\left[\int_{0}^{1}\left(\frac{p_{i t}}{P_{t}}\right)^{-\theta} d i\right]^{-1} A_{t} F\left(K_{t}, N_{t}\right) .
$$

Equilibria. An equilibrium for $\left\{C_{t}, L_{t}, N_{t}, K_{t}\right\},\left\{p_{t}, P_{t}, W_{t}, U_{t}\right\}$, and $\left\{i_{t} \geq 0, \tau_{t}^{c}, \tau_{t}^{n}, \tau_{t}^{k}, s_{t}^{I}, \tau_{t}^{d}\right\}$ is characterized by (11), (13), (30), (34), (15), (16), together with (6) and

$$
C_{t}+G_{t}+K_{t+1}-(1-\delta) K_{t}=\left[\sum_{j=0}^{t+1} \varpi_{j}\left(\frac{p_{t-j}}{P_{t}}\right)^{-\theta}\right]^{-1} A_{t} F\left(K_{t}, N_{t}\right) .
$$

As before, we do not need to keep track of the budget constraints, since lump sum taxes can be adjusted to satisfy them. 
First-best allocation. At the first-best allocation, the marginal rate of technical substitution between any two varieties must be equal to one, so

$$
c_{i t}=C_{t} ; g_{i t}=G_{t} ; i_{i t}=I_{t}
$$

The efficiency conditions for the aggregates are:

$$
\begin{gathered}
\frac{u_{C}\left(C_{t}, L_{t}, \xi_{t}\right)}{u_{L}\left(C_{t}, L_{t}, \xi_{t}\right)}=\frac{1}{A_{t} F_{n}\left(\frac{K_{t}}{N_{t}}\right)}, \\
u_{C}\left(C_{t}, L_{t}, \xi_{t}\right)=E_{t} \beta u_{C}\left(C_{t+1}, L_{t+1}, \xi_{t+1}\right)\left[A_{t+1} F_{k}\left(\frac{K_{t+1}}{N_{t+1}}\right)+1-\delta\right] \\
C_{t}+G_{t}+K_{t+1}-(1-\delta) K_{t}=A_{t} F\left(K_{t}, N_{t}\right)
\end{gathered}
$$

and

$$
N_{t}=1-L_{t}
$$

Policy away from the zero bound. As before, there is a tax on pure profits ${ }^{12}$, that we assume to be arbitrarily close to one. As in the model without capital, away from the zero bound, monetary policy can implement the first-best allocation with constant taxes and constant prices $p_{t}=P_{t}=p_{-1}=P$. The implementation follows the same logic as in the model without capital. Taxes on consumption and leisure must offset the monopoly pricing distortion. Here we choose to set consumption taxes to zero, $\tau^{c}=0$ and the labor tax to $\tau^{n}=\frac{-1}{\theta-1}$. The nominal interest rate is set equal to the natural rate of interest.

For a given $s_{t}^{I}$, the tax rate on capital income, $\tau_{t+1}^{k}$, and the investment tax credit, $s_{t+1}^{I}$, must be chosen to satisfy the marginal condition for capital (30). If the capital income tax is not used, $\tau_{t}^{k}=0$, a constant investment tax credit, $s^{I}=\frac{1}{\theta}$, satisfies the condition at the first-best. This investment subsidy is required to offset the effect of the distortion arising from monopoly pricing on capital accumulation. Instead, if $s_{t}^{I}=0$ for all $t$, then the capital income tax, $\tau_{t+1}^{k}$, must be moving with shocks in order to implement the first-best allocation. It is no longer the case that the first-best can be implemented with constant taxes, away from the zero bound ${ }^{13}$. This is the case because we assume, as is standard, that firms can deduct depreciation expenses from the capital income tax/subsidy, i.e. the tax is paid on $\left(U_{t}-\delta P_{t}\right) K_{t}$. If, instead, the tax was paid on the gross return $U_{t} K_{t}$, setting a constant tax, $\tau^{k}$, with $\tau^{k}=\frac{-1}{\theta-1}$, would be consistent with the optimal allocation.

Finally, the nominal wage must satisfy $P=\frac{\theta}{\theta-1} \frac{W_{t}}{A_{t} F_{n}\left(\frac{K_{t}}{N_{t}}\right)}$ and the rental cost of capital $U_{t}$ must satisfy (33).

\footnotetext{
${ }^{12}$ In practice, it may be difficult to distinguish capital income from pure profits. However, a tax on profits can be replicated by a tax on total income from capital and profits, together with an investment subsidy.

${ }^{13}$ Standard New Keynesian models usually have labor only and assume taxes are not flexible. If instead they considered capital, the nonflexiblity of taxes would be costly.
} 
Policy at the zero bound. When the natural rate of interest is negative, the first-best can be implemented with time-varying taxes, as in the simple model with no capital. The intertemporal condition for noncontingent bonds with a constant price level, (23), when $i_{t}=0$, imposes the same restrictions on the path of consumption taxes. As before, the labor income tax will have to compensate for the movements in the consumption tax, satisfying

$$
\frac{u_{C}\left(C_{t}, L_{t}, \xi_{t}\right)}{u_{L}\left(C_{t}, L_{t}, \xi_{t}\right)}=\frac{\theta}{\theta-1} \frac{1+\tau_{t}^{c}}{1-\tau_{t}^{n}} \frac{1}{A_{t} F_{n}\left(\frac{K_{t}}{N_{t}}\right)},
$$

with $\frac{\theta}{\theta-1} \frac{1+\tau_{t}^{c}}{1-\tau_{t}^{n}}=1$. Both taxes can be predetermined.

Either the capital income tax or the investment tax credit can be used to compensate for the changes in the consumption tax. For example, if we set $\tau_{t}^{k}=0$ for all $t$, the investment tax credit must move so as to satisfy the condition for capital accumulation:

$$
\frac{u_{C}\left(C_{t}, L_{t}, \xi_{t}\right)}{1+\tau_{t}^{c}}=E_{t}\left\{\frac{\beta u_{C}\left(C_{t+1}, L_{t+1}, \xi_{t+1}\right)}{1+\tau_{t+1}^{c}}\left[\frac{1-s_{t+1}^{I}}{1-s_{t}^{I}}(1-\delta)+\frac{1}{1-s_{t}^{I}} \frac{\theta-1}{\theta} A_{t+1} F_{k}\left(\frac{K_{t+1}}{N_{t+1}}\right)\right]\right\} .
$$

Note that while efficient investment tax policy can be done, away from the zero bound, with a constant subsidy, at the zero bound the investment tax credit cannot be constant. However, it can be predetermined.

To summarize, when the zero bound is temporarily binding, we must supplement the flexibility in consumption and labor income taxes with flexible taxes on investment or on capital income. As the increasing path of consumption taxes that is necessary to circumvent the zero bound constraint acts as an undesirable tax on capital, its effects must be counteracted with an offsetting capital income subsidy. This subsidy must remain in place as long as consumption taxes are increasing. The corresponding policy is still revenue neutral, exactly as in Section 2.8 .

\section{Sticky wages}

We have assumed so far that prices are sticky but wages are fully flexible. But, what if the relevant nominal friction was sticky wages rather than sticky prices? Would it still be possible to achieve the first-best at the zero bound? What fiscal instruments would be necessary? We answer these questions below.

An environment with sticky wages. In order to allow for sticky wages, we now consider a single household with a continuum of members indexed by $h \in[0,1]$, each supplying a differentiated labor input $n_{h t}$. Preferences of the household are described by (1), where leisure is

$$
L_{t}=1-\int_{0}^{1} n_{h t} d h
$$

The differentiated labor varieties aggregate up to the labor input $N_{t}$, used in production, according to the Dixit-Stiglitz aggregator

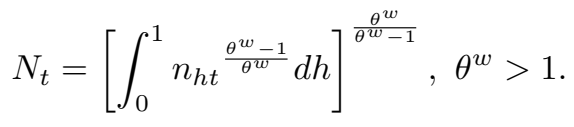


There is a single good produced, $Y_{t}$, that uses labor, $N_{t}$, and capital, $K_{t}$, and that can be used for private or public consumption and capital accumulation, according to

$$
C_{t}+G_{t}+K_{t+1}-(1-\delta) K_{t}=Y_{t}=A_{t} F\left(K_{t}, N_{t}\right)
$$

The good is produced by a representative firm that behaves competitively. Each member of the household, that supplies a differentiated labor variety, behaves under monopolistic competition. They set wages as in Calvo (1983), with probability of being able to revise the wage $1-\alpha^{w}$. This lottery is also i.i.d. across workers and over time. The workers that are not able to set wages in period 0, all share the same wage $w_{-1}$. Other prices are taken as given. There is a complete set of state contingent assets. We consider an additional tax, a payroll tax on the wage bill paid by firms, $\tau_{t}^{p}$. As long as an investment tax credit is used, the capital income tax is redundant, so we set it to zero, $\tau_{t}^{k}=0$.

First-best allocation. The feasible allocation that now maximizes the utility of the representative household must have

$$
n_{h t}=N_{t}, \text { for all } h, \text { and } t
$$

These conditions equalize marginal rates of substitution to marginal rates of transformations across varieties of labor. Furthermore, the same efficiency conditions for the aggregates as above, (39), (40), (41) and (42) must hold.

Equilibria with sticky wages. The representative firm minimizes $\int_{0}^{1} w_{h t} n_{h t} d h$, where $w_{h t}$ is the wage of the $h$-labor, for a given aggregate $N_{t}$, subject to (45). The demand for $n_{h t}$ is

$$
n_{h t}=\left(\frac{w_{h t}}{W_{t}}\right)^{-\theta^{w}} N_{t}
$$

where $W_{t}$ is the aggregate wage level, given by

$$
W_{t}=\left[\int_{0}^{1} w_{h t}{ }^{1-\theta^{w}} d h\right]^{\frac{1}{1-\theta^{w}}} .
$$

It follows that $\int_{0}^{1} w_{h t} n_{h t} d h=W_{t} N_{t}$.

The firm maximizes profits, subject to the production function in (46), taking prices of both output, $P_{t}$, and inputs, $W_{t}$ and $U_{t}$, as given. This implies

$$
\frac{U_{t}}{\left(1+\tau_{t}^{p}\right) W_{t}}=\frac{F_{k}\left(\frac{K_{t}}{N_{t}}\right)}{F_{n}\left(\frac{K_{t}}{N_{t}}\right)}
$$

and

$$
P_{t}=\frac{\left(1+\tau_{t}^{p}\right) W_{t}}{A_{t} F_{n}\left(\frac{K_{t}}{N_{t}}\right)}
$$


The period-by-period budget constraints for the household are (28) with $\Pi_{t}=0$ for all $t$. We assume that wages are set before labor income taxes ${ }^{14}$. The optimal wage setting conditions by the monopolistic competitive workers are now

$$
w_{t}=\frac{\theta^{w}}{\theta^{w}-1} E_{t} \sum_{j=0}^{\infty} \eta_{t, j}^{w} \frac{u_{L}(t+j)}{u_{C}(t+j)} \frac{\left(1+\tau_{t+j}^{c}\right) P_{t+j}}{\left(1-\tau_{t+j}^{n}\right)}
$$

with

$$
\eta_{t, j}^{w}=\frac{\left(1-\tau_{t+j}^{n}\right)\left(\alpha^{w} \beta\right)^{j} \frac{u_{C}(t+j)}{\left(1+\tau_{t+j}^{c}\right) P_{t+j}}\left(W_{t+j}\right)^{\theta^{w}} N_{t+j}}{E_{t} \sum_{j=0}^{\infty}\left(1-\tau_{t+j}^{n}\right)\left(\alpha^{w} \beta\right)^{j} \frac{u_{C}(t+j)}{\left(1+\tau_{t+j}^{c}\right) P_{t+j}}\left(W_{t+j}\right)^{\theta^{w}} N_{t+j}} .
$$

The wage level (49) can be written as

$$
W_{t}=\left[\left(1-\alpha^{w}\right) w_{t}^{1-\theta^{w}}+\alpha^{w} W_{t-1}^{1-\theta^{w}}\right]^{\frac{1}{1-\theta^{w}}} .
$$

The marginal condition for the accumulation of capital is (29) with $\tau_{t}^{k}=0$, the intertemporal condition for noncontingent bonds is (13), while market clearing for the final good is given by (46).

Using (48), we can write (44) as

$$
N_{t}=\left[\int_{0}^{1}\left(\frac{w_{h t}}{W_{t}}\right)^{-\theta^{w}} d h\right]^{-1}\left(1-L_{t}\right)
$$

From (49), it must be that $\int_{0}^{1}\left(\frac{w_{h t}}{W_{t}}\right)^{-\theta^{w}} d h \geq 1$. This means that for a given total time dedicated to work, $1-L_{t}$, the resources available for production are maximized when there is no wage dispersion. Using (55), we can write the resources constraint as

$$
C_{t}+G_{t}+K_{t+1}-(1-\delta) K_{t}=A_{t} F\left(K_{t},\left[\int_{0}^{1}\left(\frac{w_{h t}}{W_{t}}\right)^{-\theta^{w}} d h\right]^{-1}\left(1-L_{t}\right)\right),
$$

which is, for sticky wages, the analog to the resource constraint with a cost of price dispersion under sticky prices, (38).

An equilibrium for $\left\{C_{t}, L_{t}, N_{t}, K_{t}\right\},\left\{P_{t}, w_{t}, W_{t}, U_{t}\right\},\left\{i_{t} \geq 0, \tau_{t}^{c}, \tau_{t}^{n}, \tau_{t}^{p}, s_{t}^{I}, \tau_{t}^{d}\right\}$, is characterized by conditions (13), (30) with $\tau_{t}^{k}=0,(50),(51),(52)$ and (53), (54), (46) and

$$
1-L_{t}=N_{t} \sum_{j=0}^{t+1} \varpi_{j}^{w}\left(\frac{w_{t-j}}{W_{t}}\right)^{-\theta^{w}}
$$

where $\varpi_{j}^{w}$ is the share of household members that have set wages $j$ periods before, $\varpi_{j}^{w}=\left(\alpha^{w}\right)^{j}\left(1-\alpha^{w}\right)$, $j=0,2, \ldots, t$, and $\varpi_{t+1}^{w}=\left(\alpha^{w}\right)^{t+1}$, which is the share of workers that have never set wages, and charge the exogenous wage $w_{-1}$. As before, we do not need to keep track of the budget constraints, since lump sum taxes adjust to satisfy the budget.

\footnotetext{
${ }^{14}$ This is analogous to the assumption that prices are set before consumption taxes. For our policy to work, it is important that the posted wage be exclusive of the labor income tax. In other words, unless the Calvo shock allows for a revision in the wage, and for a given aggregate price level, reductions in labor income taxes increase the real wage of consumers, but leave the real cost of labor for firms unchanged.
} 
We can now show that it is possible to use taxes to implement the first-best allocation when the zero bound constraint binds.

Implementing the first-best when wages are sticky. Efficiency requires that labor be the same across varieties. In order for this to be an equilibrium outcome it must be that wages be constant over time and equal to $w_{-1}$. It is useful to write the wage setting condition, (52), in recursive form, as

$$
w_{t}=\eta_{t, 0}^{w} \frac{\theta^{w}}{\theta^{w}-1} \frac{u_{L}(t)}{u_{C}(t)} \frac{\left(1+\tau_{t}^{c}\right) P_{t}}{\left(1-\tau_{t}^{n}\right)}+\left(1-\eta_{t, 0}^{w}\right) E_{t} w_{t+1} .
$$

It follows that for $w_{t}=w_{-1}$, the wage setting condition is the same as if wages were flexible.

The conditions that define an equilibrium with constant wages $w_{t}=w_{-1}$ for $\left\{C_{t}, L_{t}, N_{t}, K_{t}\right\},\left\{P_{t}, U_{t}\right\}$, $\left\{i_{t} \geq 0, \tau_{t}^{c}, \tau_{t}^{n}, \tau_{t}^{p}, s_{t}^{I}\right\}$ become

$$
\begin{gathered}
\frac{u_{C}\left(C_{t}, L_{t}, \xi_{t}\right)}{\left(1+\tau_{t}^{c}\right) P_{t}}=\left(1+i_{t}\right) E_{t}\left[\frac{\beta u_{C}\left(C_{t+1}, L_{t+1}, \xi_{t+1}\right)}{\left(1+\tau_{t+1}^{c}\right) P_{t+1}}\right], \\
\frac{u_{C}\left(C_{t}, L_{t}, \xi_{t}\right)}{u_{L}\left(C_{t}, L_{t}, \xi_{t}\right)}=\frac{\theta^{w}}{\theta^{w}-1} \frac{\left(1+\tau_{t}^{c}\right)\left(1+\tau_{t}^{p}\right)}{1-\tau_{t}^{n}} \frac{1}{A_{t} F_{n}\left(\frac{K_{t}}{N_{t}}\right)}, \\
\frac{u_{C}\left(C_{t}, L_{t}, \xi_{t}\right)}{1+\tau_{t}^{c}}=E_{t}\left\{\frac{\beta u_{C}\left(C_{t+1}, L_{t+1}, \xi_{t+1}\right)}{1+\tau_{t+1}^{c}}\left[\frac{1-s_{t+1}^{I}}{1-s_{t}^{I}}(1-\delta)+\frac{1}{1-s_{t}^{I}} A_{t+1} F_{k}\left(\frac{K_{t+1}}{N_{t+1}}\right)\right]\right\},
\end{gathered}
$$

together with the firms' conditions (50) and (51) with $W_{t}=w_{-1}$, the market clearing condition (46) and $N_{t}=1-L_{t}$.

Away from the zero bound, the first-best can be implemented with a state-contingent nominal interest rate and a constant subsidy, that eliminates the markup distortion. The constant subsidy can be given with any of the taxes, on consumption, labor income, or the payroll tax. The investment tax credit must be set to zero. The price level, $P_{t}$, must move with the shocks to satisfy (51) and the user cost of capital $U_{t}$ must satisfy (50).

When nominal interest rates are zero, it is possible to use unconventional fiscal policy to implement the first-best exactly as in the case of sticky prices and flexible wages that we analyzed before - an interesting robustness property of unconventional fiscal policy. To see this, set the payroll tax to zero $\tau_{t}^{p}=0$, then given $\tau_{t}^{c}$, (58) can be satisfied by an appropriate choice of $\tau_{t+1}^{c}$, (59) by an appropriate choice of $\tau_{t}^{n}$, (60) by an appropriate choice of $s_{t+1}^{I}$, and (50) and (51) by $P_{t}$ and $U_{t}$.

\section{An alternative implementation of the first-best when wages are sticky but prices are flexible.}

With sticky wages and flexible prices, it is also possible to use a different combination of taxes to implement the first-best. Indeed, it is possible to use only labor income and payroll taxes. Let the nominal interest rate be some sequence with $i_{t} \geq 0$, and let $\tau_{t}^{c}=s_{t}^{I}=0$, for all $s^{t}$. Then (58) is satisfied by $P_{t+1},(51)$ is satisfied by $\tau_{t}^{p}$, (59) is satisfied by $\tau_{t}^{n}$, and (50) by $U_{t}$. The only restrictions on the equilibrium allocations are the 
resource constraints (46) together with (60) once $\tau_{t}^{c}=s_{t}^{I}=0$. These are conditions that are satisfied at the first-best.

When the nominal interest rate is zero, the real interest rate can still be negative as long as there is consumer price inflation. As before, that can be accomplished by consumption taxes that increase over time. But with flexible prices, it can also be accomplished by costless producer price inflation (equation (58)). However, because flexible-price firms set the price as a mark up over marginal cost (equation (51)), there is price inflation if there is inflation in wages gross of payroll taxes. Inflation in payroll taxes avoids the costs of wage dispersion. The labor income tax is used to compensate for the distortion in the intratemporal margin created by the payroll tax (equation (59)). In order to eliminate the mark up distortion in this margin, it must be that $\frac{\theta^{w}-1}{\theta^{w}} \frac{1+\tau_{t}^{p}}{1-\tau_{t}^{n}}=1$, so that the increasing payroll tax is compensated by a decreasing labor income $\operatorname{tax}^{15}$.

Sticky prices and sticky wages. The case of both sticky prices and wages is of a different nature. It is still possible to use unconventional fiscal policy to replicate the effects of negative nominal interest rates and hence circumvent the zero bound constraint. This can be done through the same combination of timevarying consumption and labor taxes, and of a time varying investment tax credit, that we considered above. However, replicating the effects of negative nominal interest rate is not enough to implement the first-best solution. Indeed, even away from the zero bound, monetary policy alone cannot undo the effects of the real rigidities caused by both sticky prices and wages. It is still possible to achieve the first-best, but it is necessary to use state-contingent fiscal policy also when the zero bound constraint is not binding. To see this, notice that, when both prices and wages are rigid, it must be that both producer prices and wages before labor taxes are constant. If tax policy was not state contingent, equations (51) with $W_{t}=w_{-1}$, and (59) would imply that marginal rates of substitution and transformation could not be state contingent, which is obviously not the case in general for the first-best allocation.

When there are both sticky prices and wages, the conditions for the implementation of the first-best are the ones described above, with two differences. The first difference is that the price level in (58) must be constant over time, $P_{t}=P=p_{-1}$. The second is that the markup in the goods prices must be taken into account. This means that equation (59) is replaced by

$$
\frac{u_{C}\left(C_{t}, L_{t}, \xi_{t}\right)}{u_{L}\left(C_{t}, L_{t}, \xi_{t}\right)}=\frac{\theta}{(\theta-1)} \frac{\theta^{w}}{\left(\theta^{w}-1\right)} \frac{\left(1+\tau_{t}^{p}\right)\left(1+\tau_{t}^{c}\right)}{1-\tau_{t}^{n}} \frac{1}{A_{t} F_{n}\left(\frac{K_{t}}{N_{t}}\right)},
$$

equation (60) is replaced by (43), and equation (51), by

$$
P=\frac{\theta}{\theta-1} \frac{\left(1+\tau_{t}^{p}\right) W}{A_{t} F_{n}\left(\frac{K_{t}}{N_{t}}\right)} .
$$

\footnotetext{
${ }^{15}$ It is also important for this result that the wage be sticky exclusive of the payroll tax. One way to think about it is that we are adjusting the employer part of the payroll tax. The wage that is posted does not include the employer part of the payroll tax.
} 
Away from the zero bound, in order to implement the first-best, it is enough to use payroll and labor income taxes. Payroll taxes satisfy condition (62); labor income taxes satisfy condition (61) with $\frac{\theta}{\theta-1} \frac{\theta^{w}}{\theta^{w-1}} \frac{1+\tau_{t}^{p}}{1-\tau_{t}^{n}}=1$, so that (61) coincides with the efficiency condition (39). There must also be a constant investment subsidy, $s^{I}=\frac{1}{\theta}$, so that (43) becomes the intertemporal efficiency condition (40). The nominal interest rate must be equal to the natural rate of interest $u_{C}\left(C_{t}, L_{t}, \xi_{t}\right)=\left(1+i_{t}\right) E_{t}\left[\beta u_{C}\left(C_{t+1}, L_{t+1}, \xi_{t+1}\right)\right]$ , to satisfy (58). The user cost of capital $U_{t}$ must satisfy (50).

At the zero bound, real interest rates can be negative when producer prices are stable, if consumption taxes grow over time (equation (58)). When both prices and wages are stable, the necessary adjustments in the real wage faced by the firms are achieved with the payroll tax. The other taxes must compensate for the distortions created by the consumption taxes and the payroll taxes, so that the efficiency conditions (39) and (40) may be verified. Condition (61) can be satisfied with a choice of $\tau_{t}^{n}$ so that (39) holds. The joint taxes $\tau_{t}^{c}, \tau_{t}^{n}$, and $\tau_{t}^{p}$, must be such that production is subsidized and the joint mark up distortions from the production and labor markets are eliminated. The intertemporal condition (43) is satisfied by the investment subsidy $s_{t+1}^{I}$, so that (40) holds. Equation (50) determines the user cost of capital $U_{t}$. The resource constraint without price or wage dispersion is the only remaining restriction to the optimal policy problem. It follows that the resulting allocation is the one corresponding to the first-best.

\section{General results}

So far, we have shown how fiscal policy can be used to achieve the first-best solution when the zero bound constraint binds. This is a useful benchmark to consider, since it is the one the New Keynesian literature focuses on. It does therefore make clear the comparisons with the existing literature. We also argued that, as the first-best can be achieved, the optimal policy is time consistent. All these results hinge, of course, on the government being able to raise lump-sum taxes to pay for government spending and the subsidies that eliminate the mark-up distortions.

We now rule out direct lump-sum taxation so that $T_{t}=0$ for all $t$, following the second-best Ramsey literature. It is well known that in this case the first-best cannot, in general, ${ }^{16}$ be implemented. As it turns out, unconventional fiscal policy can circumvent the zero bound also at the second-best. The result, however, is more general: The set of implementable allocations is the same whether the zero bound constraint is imposed or $\operatorname{not}^{17}$.

We also partially characterize the second-best allocation and the fiscal policy that supports it. We show that the second-best features price stability. While the optimal allocation and relative prices are in general different from before, the way taxes are used to overcome the zero bound is essentially the same.

The second-best is in general not time consistent. However, since the zero bound does not constrain

\footnotetext{
${ }^{16}$ Even if $T_{t}=0$, for all $t$, under certain conditions the first best may be attained.

${ }^{17}$ In the Appendix, we further extend these results to an environment with idiosyncratic shocks and a general distribution of initial prices, where it is neither feasible nor optimal to eliminate price dispersion.
} 
the set of implementable equilibrium allocations, this time-inconsistency is unrelated to the zero bound constraint.

\subsection{Implementable allocations}

Equilibria without lump sum taxes. We study the model with capital but, for simplicity, we allow for flexible wages, so that payroll taxes are redundant. Thus, we only consider taxes on consumption, labor income, capital income, investment, and profits. This is the model in Section 3, with the only difference that $T_{t}=0$ for $t \geq 0$. The household budget constraint is (28) with $T_{t}=0$, together with a terminal condition $\lim _{T \rightarrow \infty} Q_{0, T+1} \bar{B}_{T}+E_{0} Q_{0, T+1} B_{T, T+1} \geq 0$. The present value budget constraint for the household as of period zero, with equality, is

$$
\begin{aligned}
& E_{0} \sum_{t=0}^{\infty} Q_{0, t}\left[\left(1+\tau_{t}^{c}\right) P_{t} C_{t}-\left(1-\tau_{t}^{n}\right) W_{t} N_{t}\right]=E_{0} \sum_{t=0}^{\infty} Q_{0, t}\left(1-\tau_{t}^{d}\right) \Pi_{t}+ \\
& \bar{B}_{0}+B_{-1,0}+(1-\delta)\left(1-s_{0}^{I}\right) P_{0} K_{0}+\left(1-\tau_{0}^{k}\right) U_{0} K_{0}+\tau_{0}^{k} \delta P_{0} K_{0} .
\end{aligned}
$$

with $\Pi_{t}=\int_{0}^{1}\left(p_{i t}-\frac{W_{t}}{A_{t} F_{n}(t)}\right)\left(\frac{p_{i t}}{P_{t}}\right)^{-\theta} Y_{t} d i$.

An equilibrium for $\left\{C_{t}, L_{t}, N_{t}, K_{t}\right\},\left\{p_{t}, P_{t}, W_{t}, U_{t}\right\}$, and $\left\{i_{t} \geq 0, \tau_{t}^{c}, \tau_{t}^{n}, \tau_{t}^{k}, s_{t}^{I}, \tau_{t}^{d}\right\}$ is characterized by (11), (13), (16), (34), (15),(30), (38), (6), together with the following implementability condition:

$$
\begin{aligned}
& E_{0} \sum_{t=0}^{\infty} \beta^{t}\left[u_{C}\left(C_{t}, L_{t}, \xi_{t}\right) C_{t}-u_{L}\left(C_{t}, L_{t}, \xi_{t}\right) N_{t}\right]=E_{0} \sum_{t=0}^{\infty} \beta^{t} u_{C}\left(C_{t}, L_{t}, \xi_{t}\right) \frac{\left(1-\tau_{t}^{d}\right) \Pi_{t}}{\left(1+\tau_{t}^{c}\right) P_{t}}+ \\
& u_{C}\left(C_{0}, L_{0}, \xi_{0}\right) \frac{\bar{B}_{0}+B_{-1,0}}{\left(1+\tau_{0}^{c}\right) P_{0}}+u_{C}\left(C_{0}, L_{0}, \xi_{0}\right)\left[(1-\delta) \frac{\left(1-s_{0}^{I}\right) K_{0}}{\left(1+\tau_{0}^{c}\right)}+\frac{\left(1-\tau_{0}^{k}\right) \frac{U_{0}}{P_{0}}+\tau_{0}^{k} \delta}{\left(1+\tau_{0}^{c}\right)} K_{0}\right],
\end{aligned}
$$

which was derived from (63), using (11) and (12)

Circumventing the zero bound constraint. In order to show that the zero bound does not restrict the set of equilibrium allocations, consider an allocation and a sequence of prices $\left\{p_{t}, P_{t}, W_{t}, U_{t}, C_{t}, L_{t}, N_{t}, K_{t}\right\}$ that satisfy the equilibrium conditions above, but do not necessarily satisfy the zero bound constraint. Let $\left\{i_{t}, \tau_{t}^{c}, \tau_{t}^{n}, \tau_{t}^{k}, s_{t}^{I}, \tau_{t}^{d}\right\}$ be a sequence of taxes and nominal interest rates that supports those prices and allocation. The same allocation and process for prices can be implemented with another sequence for taxes and interest rates $\left\{\tilde{\imath}_{t}, \tilde{\tau}_{t}^{c}, \tilde{\tau}_{t}^{n}, \tilde{\tau}_{t}^{k}, \widetilde{s}_{t}^{I}, \tilde{\tau}_{t}^{d}\right\}$, in such a way that the zero bound constraint is satisfied. We now explain how to construct the taxes that implement the original allocation with the new interest rate $\tilde{\imath}_{t}=\max \left\{i_{t}, 0\right\}$.

In order to perform this construction recursively, consider a history $s^{t}$, and assume that $\tilde{\tau}_{t}^{c}$ has been chosen, with $\tilde{\tau}_{0}^{c}=\tau_{0}^{c}$. We construct $\tilde{\tau}_{t+1}^{c}$ in such a way that

$$
\frac{1}{1+\tilde{\imath}_{t}}=E_{t}\left[\frac{\beta u_{C}\left(C_{t+1}, L_{t+1}, \xi_{t+1}\right)}{u_{C}\left(C_{t}, L_{t}, \xi_{t}\right)} \frac{P_{t}}{P_{t+1}} \frac{1+\tilde{\tau}_{t}^{c}}{1+\tilde{\tau}_{t+1}^{c}}\right]
$$

holds. The ratio $\frac{1+\tilde{\tau}_{t+1}^{c}}{1+\tilde{\tau}_{t}^{c}} / \frac{1+\tau_{t+1}^{c}}{1+\tau_{t}^{c}}$ can be predetermined, which we assume is the case. Given a path for the 
consumption $\operatorname{tax}\left\{\tilde{\tau}_{t}^{c}\right\}$, it is possible to find a path for the profit tax $\left\{\tilde{\tau}_{t}^{d}\right\}$ such that

$$
\frac{1-\tilde{\tau}_{t}^{d}}{1+\tilde{\tau}_{t}^{c}}=\frac{1-\tau_{t}^{d}}{1+\tau_{t}^{c}}
$$

This keeps the weights in the price setting equation (15) unchanged, and, therefore, also ensure that (34) is satisfied. The budget constraint (64) is also left unchanged. We then set labor taxes as

$$
\frac{1-\tilde{\tau}_{t}^{n}}{1+\tilde{\tau}_{t}^{c}}=\frac{1-\tau_{t}^{n}}{1+\tau_{t}^{c}}
$$

that satisfies the household's intratemporal condition (11). Finally, we set $\tilde{\tau}_{t}^{k}=\tau_{t}^{k}$, for $t \geq 0$, and $\widetilde{s}_{0}^{I}=s_{0}^{I}$, and construct $\widetilde{s}_{t+1}^{I}$, given $\widetilde{s}_{t}^{I}$, to satisfy

$$
\frac{u_{C}\left(C_{t}, L_{t}, \xi_{t}\right)}{\left(1+\tilde{\tau}_{t}^{c}\right)}=E_{t}\left\{\frac{\beta u_{C}\left(C_{t+1}, L_{t+1}, \xi_{t+1}\right)}{\left(1+\tilde{\tau}_{t+1}^{c}\right)}\left[\frac{\left(1-\widetilde{s}_{t+1}^{I}\right)}{\left(1-\widetilde{s}_{t}^{I}\right)}(1-\delta)+\frac{\left(1-\tilde{\tau}_{t+1}^{k}\right) \frac{U_{t+1}}{P_{t+1}}+\tilde{\tau}_{t+1}^{k} \delta}{\left(1-\widetilde{s}_{t}^{I}\right)}\right]\right\}
$$

Since $\tilde{\tau}_{0}^{k}=\tau_{0}^{k}$ and $\widetilde{s}_{0}^{I}=s_{0}^{I}$, the budget constraint (64) is satisfied.

These new paths for the tax rates and interest rates $\left\{\tilde{\imath}_{t}, \tilde{\tau}_{t}^{c}, \tilde{\tau}_{t}^{n}, \tilde{\tau}_{t}^{k}, \widetilde{s}_{t}^{I}, \tilde{\tau}_{t}^{d}\right\}$ satisfy all the equilibrium conditions, leaving the variables $\left\{p_{t}, P_{t}, W_{t}, U_{t}, C_{t}, L_{t}, N_{t}, K_{t}\right\}$ unchanged, and satisfying the zero bound constraint.

Here, we have not imposed restrictions on the tax rates, but there is one natural restriction on the profit tax that may apply, that it cannot be greater than one. We also don't allow for the profit tax to be exactly one, since in that case, firms would always have zero profits, regardless of their choices. It is easy to see that as $\tau_{t}^{d}<1$ for all $t$, then $\tilde{\tau}_{t}^{d}<1$ for all $t$. Notice that whenever $i_{t}<0$, and therefore $\tilde{\imath}_{t}=0$, then $\frac{1+\tilde{\tau}_{t+1}^{c}}{1+\tilde{\tau}_{t}^{c}}>\frac{1+\tau_{t+1}^{c}}{1+\tau_{t}^{c}},{ }^{18}$ and when $i_{t} \geq 0$, then $\frac{1+\tilde{\tau}_{t+1}^{c}}{1+\tilde{\tau}_{t}^{c}}=\frac{1+\tau_{t+1}^{c}}{1+\tau_{t}^{c}}$. It follows that $\tilde{\tau}_{t}^{c} \geq \tau_{t}^{c}$, so that (65) implies that $\tilde{\tau}_{t}^{d} \leq \tau_{t}^{d}<1$.

Revenue neutrality. The tax policy that circumvents the zero bound is revenue neutral in the same sense as in the case with lump sum taxes. We have considered two economies: One fictitious economy where nominal interest rates could be negative, and the economy restricted by the zero bound. The two economies share the same equilibrium allocations. Those can be decentralized with either variable interest rate policy or with variable tax policy, or with a combination of both. Regardless of the particular decentralization, each allocation satisfies the budget constraint (64), with zero lump sum taxes, $T_{t}=0$, and common values for the initial taxes $\tau_{0}^{c}, \tau_{0}^{k}, s_{0}^{I}$. This means that the alternative decentralizations finance the same sequence of government consumption.

\footnotetext{
${ }^{18}$ This is where the assumption that $\frac{1+\tilde{\tau}_{t+1}^{c}}{1+\tilde{\tau}_{t}^{c}} / \frac{1+\tau_{t+1}^{c}}{1+\tau_{t}^{c}}$ is predetermined is important.
} 


\subsection{Second best.}

We now describe the policy that circumvents the zero bound constraint at the second-best ${ }^{19}$. In order to do this, we first show that profits should be fully taxed. We then use this to show that price stability is optimal. For this reason, the description of the policy that overcomes the zero bound is essentially the same as in the first-best case. We also discuss the time-consistency of policy.

Full taxation of profits. In this model, current firms profits are pure rents, so that they should be taxed fully. However, future profit taxes are distortionary, since, as equation (15) makes clear, they affect the weights in the price setting decision of firms. In this second-best environment, it could be optimal for the Ramsey planner to abstain from fully taxing profits in order to obtain a particular effect on the prices set by firms. It turns out, however, that it is still optimal to tax all profits at the limiting rate of $100 \%$.

To see this, note that for any $t$, increasing $\tau_{t}^{d}$ relaxes the implementability condition (64) as long as aggregate profits $\Pi_{t}$ are positive, which we assume to be the case. The only other equilibrium condition which features profit taxes is (15). The key is to realize that profit taxes enter this last set of conditions only through the growth rates $\left\{\frac{1-\tau_{t+1}^{d}}{1-\tau_{t}^{d}}\right\}_{t=0}^{\infty}$, as is made clear by rewriting (15) recursively:

$$
\frac{1}{\eta_{t, 0}}=1+\alpha E_{t}\left[\frac{\beta u_{C}\left(C_{t+1}, L_{t+1}, \xi_{t+1}\right)}{u_{C}\left(C_{t}, L_{t}, \xi_{t}\right)} \frac{P_{t}}{P_{t+1}} \frac{\left(1-\tau_{t+1}^{d}\right)\left(1+\tau_{t}^{c}\right)}{\left(1-\tau_{t}^{d}\right)\left(1+\tau_{t+1}^{c}\right)}\left(\frac{P_{t+1}}{P_{t}}\right)^{\theta} \frac{Y_{t+1}}{Y_{t}} \frac{1}{\eta_{t+1,0}}\right] .
$$

Then note that a sequence of growth rates $\left\{\frac{1-\tau_{t+1}^{d}}{1-\tau_{t}^{d}}\right\}_{t=0}^{\infty}$ determines $\left\{\tau_{t}^{d}\right\}$ up to a scaling factor determined by $\tau_{0}^{d}$. In particular, it is possible to let $\tau_{0}^{d}$ go to one, so that the whole path $\left\{\tau_{t}^{d}\right\}$ converges to one, while still featuring the same growth rates $\left\{\frac{1-\tau_{t+1}^{d}}{1-\tau_{t}^{d}}\right\}_{t=0}^{\infty}$. This choice is optimal since it relaxes the implementability condition (64) to the greatest possible extent. In summary, it is optimal to choose a sequence of profit taxes $\left\{\tau_{t}^{d}\right\}$ that is arbitrarily close to one. It is possible to do this in a way that matches any sequence of growth rates $\left\{\frac{1-\tau_{t+1}^{d}}{1-\tau_{t}^{d}}\right\}_{t=0}^{\infty}$. This ensures that (15) will be verified. We can therefore focus on the other tax instruments and implementability conditions.

Price stability. It is also straightforward to show that price dispersion is not part of the second-best solution. To see this notice, first, that for any $P_{0}$ and $U_{0}$, the initial taxes $\tau_{0}^{c}, \tau_{0}^{k}$, and $s_{0}^{I}$, can be chosen so that the value of the right hand side of the implementability condition (64) remains unchanged. ${ }^{20}$ Thus, this condition is the same with or without price dispersion. But the resource constraint with price dispersion will have $\left[\int_{0}^{1}\left(\frac{p_{i t}}{P_{t}}\right)^{-\theta} d i\right]^{-1}<1$, which reduces resources available for consumption and leisure. These are the only two implementability conditions when there is no price dispersion, since, as we saw before, all the other conditions are satisfied for a constant price level. It follows that it is optimal to eliminate price dispersion,

\footnotetext{
${ }^{19}$ Notice that the initial taxes, $\tau_{0}^{c}, s_{0}^{I}$ and $\tau_{0}^{k}$, are lump sum taxes, and that under certain conditions they can be used to achieve the first best.

${ }^{20} \mathrm{In}$ order for this to be the case it must be that there are no restrictions on the tax rates.
} 
even if the solution is a second-best. The reason for this is that, when final goods can be taxed, it is not optimal to distort production, as in Diamond and Mirrlees (1971).

We have therefore shown that second-best policy keeps the price level stable over time, just as in the first-best. The unconventional fiscal policy that overcomes the zero bound is described as in the first-best. When the real interest rate of the second-best is positive, the nominal interest rate is equal to the real interest rate and consumption taxes do not have to be adjusted for this purpose. When the real interest rates at the second-best become negative, consumption taxes have to be adjusted to overcome the zero bound constraint on the nominal rate and, as before, other taxes must also be adjusted to compensate for the undesired distortions caused on other margins. Note however that at the second-best, taxes will in general be moving with the shocks whether or not they need to be adjusted to overcome the zero bound constraint.

Time-inconsistency. When the policy instruments include lump-sum taxes, there is unconventional fiscal policy that fully neutralizes the effects of the zero bound constraint, allows to achieve the first-best, and removes the only source of time inconsistency. Instead, when lump sum taxes are not admissible, as we assumed in this section, the first-best may not be achieved and, in general, optimal policy is time inconsistent. Observing the implementability condition (64), it is clear that the initial taxation of capital is a source of time inconsistency. So is the depletion of nominal debt through the initial taxation of consumption. These are the familiar mechanisms identified in the Ramsey taxation literature. As we have just shown, the solution to the planning problem that does not impose the zero bound as a constraint, and the solution to the one that does impose the zero bound as a constraint, both yield the same second-best allocation. The time inconsistency of the second best allocation is therefore unrelated to the zero bound constraint.

\section{$6 \quad$ Numerical illustration.}

For our numerical exploration, we analyze a variant of the model in Section 5 which features capital, and allows for both sticky prices and sticky wages. We modify the model so as to incorporate adjustment costs to capital. With this modification, the model becomes very similar to one analyzed by Christiano et al. (2011); the only difference being that we allow for distortionary taxes. Monetary policy is modeled as a Taylor rule truncated at 0 . We engineer a liquidity trap by hitting the economy with a temporary discount factor shock that pushes the nominal interest rate to 0 . We contrast the behavior of the economy when fiscal policy is passive (distortionary taxes are constant) and when unconventional fiscal policy is used to replicate the non-truncated Taylor rule, and assess the required changes in taxes. We perform this comparison under a wide range of scenarios with varying degrees of price and wage stickiness. We also show how unconventional fiscal policy can be used to replicate the flexible price allocation. Finally we show how good times can be used to reverse the permanent tax changes that would otherwise occur after a liquidity trap episode, or to build a buffer in good times to limit the possibility that unconventional fiscal policy might eventually require negative labor income taxes, should the zero bound start binding again. 
So as to facilitate comparison, the functional forms we use follow Christiano et al. (2011). The accumulation equation for capital is

$$
K_{t+1}=I_{t}+(1-\delta) K_{t}-\frac{\sigma_{I}}{2}\left(\frac{I_{t}}{K_{t}}-\delta\right)^{2} K_{t}
$$

where $\sigma_{I}$ controls the magnitude of adjustment costs to capital. All production functions are Cobb-Douglas

$$
y_{i t}=A k_{i t}^{\alpha_{F}} n_{i t}^{1-\alpha_{F}}
$$

we take utility to be of the form

$$
u\left(C_{t}, L_{t}, \xi_{t}\right)=\xi_{t} \frac{\left[C_{t}^{\gamma} L_{t}^{1-\gamma}\right]^{1-\sigma}-1}{1-\sigma}
$$

and we assume that monetary policy follows a Taylor rule truncated at zero

$$
i_{t}=\max \left(Z_{t}, 0\right)
$$

where

$$
Z_{t}=\beta_{t}^{-1}\left(1+\pi_{t}\right)^{\phi_{1}\left(1-\rho_{R}\right)}\left(Y_{t} / Y\right)^{\phi_{2}\left(1-\rho_{R}\right)}\left[\beta_{t}\left(1+i_{t-1}\right)\right]^{\rho_{R}}-1
$$

and $\beta_{t}$ is the (time-varying) discount factor.

We imagine that the economy is initially at a steady state with constant consumption taxes $\bar{\tau}^{c}$, capital taxes $\bar{\tau}^{k}$, and labor income taxes $\bar{\tau}^{n}$. The revenue from these taxes is used to finance a constant level of government expenditures $\bar{G}=g \bar{Y}$. The rest is rebated to households in the form of a lump-sum transfer. We set all the other taxes to zero in steady state.

Parameter values. For taxes, we follow Drautzburg and Uhlig (2011) and set $\bar{\tau}^{c}=0.05, \bar{\tau}^{k}=0.36$, and $\bar{\tau}^{n}=0.28$.

The rest of our calibration follows Christiano et al. (2011). We take a period to be a quarter. We take the parameters in the utility function to be $\gamma=0.29, \sigma=2$, and we set the discount factor to be $\beta=0.99$. We pick $\alpha_{F}=0.33, \delta=0.02$ and choose $\sigma_{I}=17$. We choose $g=0.2$. For monetary policy, we set $\rho_{R}=0$, $\phi_{1}=1.5$ and $\phi_{2}=0$. Finally, for the stickiness parameters, we set $\alpha=\alpha^{w}=0.85$ (except when we explicitly consider flexible prices or flexible wages). Finally we take $\theta=7$ and $\theta^{w}=3$.

Shock. The shock that we consider is the same as that in Christiano et al. (2011). At time zero, the economy is in its non-stochastic steady state. At time one, agents learn that the discount factor will be $\hat{\beta}>\beta$ for $T$ periods (requiring $\beta \xi_{t+1} / \xi_{t}=\hat{\beta}$ for $T$ periods), and then return to its steady state value (so that $\xi_{t}$ is constant for $t \geq T+1$ ). The shock is sufficiently large so that the zero bound on the nominal interest rate binds between two time periods $t_{1}$ and $t_{2}$ (determined endogenously) with $1 \leq t_{1} \leq t_{2} \leq T$. We take $\hat{\beta}=1.01$ and $T=10$. 
Results. Figure 1 displays the path of the economy when taxes are kept constant at their steady-state values (inflation rates and interest rates are annualized). To facilitate comparison with Christiano et al. (2011), we start by assuming that prices are sticky but that wages are flexible. We will analyze other configurations below.

The zero bound binds in periods one through five. The shock leads to a substantial decline in investment, hours worked, output and consumption. Given that the nominal interest rate is zero, the large associated deflation implies a sharp rise in the real interest rate, which rationalizes the responses of consumption and investment. The intuition for this outcome is explained in further details in Christiano et al. (2011).

In our numerical exercise, in the spirit of Christiano et al. (2011), we simply seek to replicate the allocation that would occur, were a non-truncated Taylor rule to be used. This Taylor rule does not replicate the flexible price, flexible wage allocation. We view the Taylor rule as describing the behavior of policy in normal times, and we simply seek to remove the constraint on this behavior imposed by the zero lower bound by using unconventional fiscal policy. We could alternatively seek to replicate the flexible price, flexible wage allocation. Indeed we examine this case briefly below at the end of our description of the results. ${ }^{21}$

Figure 2 displays the path of the economy when unconventional fiscal policy is used to replicate the allocation that would arise if monetary policy followed a non-truncated Taylor rule allowing for negative nominal interest rates $i_{t}=Z_{t}$, when in fact monetary policy follows a truncated Taylor rule $i_{t}=\max \left(Z_{t}, 0\right)$ that disallows negative nominal interest rates. Compared with the allocation that arises with constant taxes, the drops in consumption and output are greatly mitigated, and investment actually booms. This outcome is intuitive. Households become more patient. As a result, they reduce consumption and increase savings. The increase in savings leads to an investment boom. Output and hours drop together with consumption because the shock initially increases price markups compared to their desired steady-state level. This causes deflation in producer prices $P_{t+1} / P_{t}-1<0 .{ }^{22}$ Increasing consumption taxes over time overturn this effect, resulting in inflation in consumer prices $\left(P_{t+1}\left(1+\tau_{t+1}^{c}\right)\right) /\left(P_{t}\left(1+\tau_{t}^{c}\right)\right)-1>0$. Since the zero bound initially binds, $i_{t}=0$ and the real interest rate $\left(1+i_{t}\right)\left(P_{t}\left(1+\tau_{t}^{c}\right)\right) /\left(P_{t+1}\left(1+\tau_{t+1}^{c}\right)\right)$ decreases. However the decrease in the real interest rate (inclusive of consumption taxes) is smaller than the increase in the discount factor, explaining the increasing path of consumption.

Figure 3 displays the corresponding path for consumption taxes, labor taxes and the investment tax credit. As explained in the main text, unconventional fiscal policy requires an increasing path of consumption taxes, a decreasing path of labor taxes, and positive investment tax credit (we keep capital taxes constant). In the interest of space, the path of profit taxes $\tau_{t}^{d}$ is not displayed: it is the mirror image of consumption taxes - it is such that $\left(1-\tau_{t}^{d}\right) /\left(1+\tau_{t}^{c}\right)$ is constant over time. In this baseline simulation, consumption taxes increase gradually from 0.05 , to 0.14 , labor taxes decrease gradually from 0.28 to 0.21 , and the investment tax credit

\footnotetext{
${ }^{21}$ Note however that in this environment with exogenous taxes, the flexible price, flexible wage allocation is not necessarily optimal.

${ }^{22}$ This is a manifestation of the aforementioned fact that the non-truncated Taylor rule does not replicate the flexible price, flexible wage allocation.
} 
(which is zero in steady state) first jumps in the first period to 0.09 and then decreases gradually towards 0 . All taxes stabilize in period six when $Z_{t}$ turns positive ${ }^{23}$.

We then consider the alternative case where prices are flexible but wages are sticky. As explained in Section 5, there are two ways to engineer an unconventional fiscal policy that replicates the allocation that would arise if a non-truncated Taylor rule were used when in fact a truncated Taylor rule is used: (i) using consumption taxes, labor taxes, and an investment tax credit as above; (ii) using labor taxes and payroll taxes. For brevity, we only present the results for (ii). Figure 4 displays the corresponding path of labor income taxes and payroll taxes. The payroll tax increases gradually over time and the labor tax decreases gradually over time. The total adjustment is 0.17 for payroll taxes and 0.12 for income taxes.

For completeness, we also consider the cases where both prices and wages are sticky. Figure 5 displays the path for consumption taxes, labor income taxes, and the investment tax credit, necessary to replicate the allocation that would arise if a non-truncated Taylor rule were used when in fact a truncated Taylor rule is used.

Finally, we briefly analyze the flexible price, flexible wage economy and how unconventional taxes can be used to implement the corresponding allocation. This also helps understand why the non-truncated Taylor rule leads to a different outcome. Figure 6 displays the path of the economy for the flexible price, flexible wage economy. It is interesting to compare this economy to the economy with sticky prices and flexible wages where unconventional taxes are used to replicate the non-truncated Taylor rule (Figure 2). The drop in consumption is significantly lower, the increase in investment is much higher, and now hours and output increase. Note that the real interest actually starts higher than in the economy where unconventional taxes are used to replicate the non-truncated Taylor rule. However, the real interest rate stays negative for the whole duration of the shock (10 periods), whereas in Figure 2, it becomes positive again in period 6. As a result consumption is now above steady state from period 6 on (in Figure 2, consumption is always below steady state). It then reverts slowly towards its steady-state value - the long transition occurs because the capital stock increased substantially because of the shock; it then slowly decreases towards its steady-state value. Unconventional taxes can be used to replicate this allocation when prices are sticky, with zero price inflation. It suffices to implement an increasing path of consumption taxes, a decreasing path for labor income taxes, and an investment tax credit as long as the real interest rate of the flexible price, flexible wage allocation is negative. Then consumption and labor income taxes are kept constant and the nominal interest rate is set equal to the real interest rate of the flexible price, flexible wage economy. These taxes are displayed in Figure 7. Note that the overall adjustments in these taxes are smaller, but last longer (10 periods instead of 6), than when unconventional fiscal policy is used to replicate the non-truncated Taylor rule (Figure 3).

\footnotetext{
${ }^{23}$ We could have alternatively chosen to decrease the capital tax instead of introducing an investment tax credit. However, the necessary reduction in the capital tax would have been large-much larger than the required adjustment in the investment tax credit. The reason is that the capital tax is a tax on the net returns to capital, while the investment tax credit acts as a subsidy on the gross return to capital.
} 
Welfare. In order to compare welfare under different scenarios, we need a welfare metric and a reference allocation. We choose to use the steady-state allocation as our reference allocation. This reference allocation is arbitrary - we could have chosen any other allocation. Table 1 computes the welfare losses associated with different scenarios compared with the welfare of the steady-state allocation. The metric that we use how much (in percentages) steady-state consumption has to be decreased for $T^{W}$ periods in order to yield the same date- 0 utility as the scenario under consideration. Formally, the table reports the value of $\lambda$ that solves

$$
\sum_{t=0}^{\infty} \beta^{t} u\left(C_{t}, L_{t}, \xi_{t}\right)=\sum_{t=0}^{T^{W}} \beta^{t} u\left((1-\lambda) C_{s s}, L_{s s}, \xi_{t}\right)+\sum_{t=T^{W}+1}^{\infty} \beta^{t} u\left(C_{s s}, L_{s s}, \xi_{t}\right) .
$$

The higher is $T^{W}$, the lower (in absolute value) are the resulting welfare effects. In the limit where $T^{W}=\infty$, the welfare effects can be interpreted as a percentage of lifetime consumption. Even though the shock that we consider leads to a very large recession, this recession is not very long-lived, and it occurs only once in our experiment economy. As a result, the corresponding welfare effects are small when computed as a fraction of lifetime consumption. We report the numbers for $T^{W}=10$ and $T^{W}=\infty$. We think that these different normalizations help appreciate the severity of the problems arising from the zero bound.

We see that the welfare gains from using unconventional fiscal policy are substantial. With sticky prices and flexible wages, these benefits are equivalent to a $0.4 \%$ permanent increase in consumption $\left(T^{W}=\infty\right)$ or equivalently a $2.2 \%$ increase in consumption for 10 quarters $\left(T^{W}=10\right)$. With flexible prices and sticky wages, these gains are $0.8 \%\left(T^{W}=\infty\right)$ and $4.3 \%\left(T^{W}=10\right)$. With both sticky prices and sticky wages, the gains become $0.2 \%\left(T^{W}=\infty\right)$ and $1.0 \%\left(T^{W}=10\right) \cdot{ }^{24}$

Finally, the last line of Table 1 reports the welfare for the flexible price, flexible wage allocation. Note that this allocation features negative welfare losses (welfare gains) over the steady-state allocation of $-3.7 \%$ $\left(T^{W}=10\right)$ and $-0.6 \%\left(T^{W}=\infty\right)$. As explained above, one way to replicate this allocation when either prices, wages are sticky, by using a different monetary policy — setting the nominal interest equal to the real interest rate of the flexible price, flexible wage economy when it is positive, and equal to zero otherwisecombined with unconventional fiscal policy - when the real interest rate of the flexible price, flexible wage economy is negative. ${ }^{25}$

Avoiding negative taxes: building a buffer in good times. Consider for simplicity our baseline calibration with only sticky prices when unconventional taxes are used to replicate the non-truncated Taylor rule. At the end of the episode, unconventional fiscal policy leads to permanently higher consumption taxes

\footnotetext{
${ }^{24}$ Table 1 shows that the welfare losses of the sticky price, sticky wage economy, and the gains from unconventional fiscal policy, are lower than under the other two scenarios (sticky prices, flexible wages, and flexible prices, sticky wages). This somehow surprising result is a manifestation of the following observation, discussed in Chirstiano et al. (2011). When the zero bound binds, more flexible prices or wages can make the outcome worse by leading to more deflation, higher real interest rates, higher markups, less consumption and less output-an effect consistent with the potentially destabilizing effects of marginal increases in price flexibility discussed in Delong and Summers (1986).

${ }^{25}$ As explained in Section 5, when both prices and wages are sticky, this allocation can still be replicated but it now requires time-varying labor income or payroll taxes even when the real interest rate of the flexible price, flexible wage economy is positive.
} 
and permanently lower labor income taxes. To the extent that one considers that labor income subsidies are hard to implement, one potential concern is that if the episode were to repeat itself (potentially several times) in the future, there would be less room to conduct unconventional fiscal policy without running into negative labor income taxes.

One way to alleviate this concern is to build a buffer of taxes in good times. We have in mind the following. At $t=10$, we impose a zero nominal interest rate and instead replicate the effects of a positive interest rate $Z_{t}$ by applying our unconventional fiscal policy in reverse, using a decreasing path for consumption taxes, and increasing path for labor taxes, and an investment tax (a negative investment tax credit). ${ }^{26}$ We can do this until consumption and labor taxes are back at their steady-state values. After that, taxes are kept constant, and monetary policy is set according to the Taylor rule $i_{t}=Z_{t}$. The corresponding path for taxes is displayed in Figure 8.

\section{Conclusion.}

In this paper we study the liquidity trap in the context of a standard New Keynesian model. We characterize jointly optimal monetary and fiscal policy. Our main result is to demonstrate how distortionary taxes can be used to replicate the effects of negative nominal interest rates and completely circumvent the zero bound problem. We label this scheme unconventional fiscal policy. It involves engineering over time an increasing path for consumption taxes, a decreasing path for labor taxes, coupled with a temporary investment tax credit or a temporary cut in capital income taxes. Moreover, numerical calibrations indicate that the magnitude of the tax changes are reasonable. Overall, the zero bound constraint on nominal interest rates is not a relevant restriction on policy when both fiscal and monetary policy are flexible.

Our results speak to the recent literature on using inefficient commitments to low future interest rates or government spending policies to circumvent the zero bound constraint in the New-Keynesian model. Unconventional fiscal policy can be used to perfectly stabilize the economy at zero cost, in a time-consistent and revenue-neutral manner. In richer or more constrained environments where lump sum taxes are unavailable, or in the presence of idiosyncratic shocks, first-best allocations cannot be implemented. However unconventional fiscal policy can still perfectly replicate the effects of negative nominal interest rates. The corresponding solution is not time-consistent, but for reasons that are unrelated to the zero bound constraint.

Crucially, unconventional fiscal policy requires flexible taxes. After witnessing the policy response to the recent crisis in the US and elsewhere, it is hard to argue for lack of flexibility of any fiscal policy. The closest example may be the 2009 temporary reduction of the VAT in the $\mathrm{UK}^{27}$. But there are also many examples of movements in sectorial or state level taxes with the purpose of stimulating spending, such as the sales

\footnotetext{
${ }^{26}$ That we choose to start building the buffer at $t=10$ is somewhat arbitrary. We could have chosen to start implementing this policy at any date after $t=6$ when $Z_{t}$ becomes positive again.

${ }^{27}$ The standard rate was reduced from $17.5 \%$ to $15 \%$, during the whole year of 2009 .
} 
tax holidays in many states in the US, ${ }^{28}$ and programs such as the Consumer Assistance to Recycle and Save (CARS) set up in June $2009^{29}$. More recently, Spain announced a reduction by half of the tax on the purchase of new homes ${ }^{30}$. In any case, our point is also normative, meaning that if taxes were not flexible, they should be made flexible.

\section{Appendix: idiosyncratic shocks.}

We now consider a more general environment where it is neither feasible, nor optimal to eliminate price dispersion. Specifically, we analyze the model of Section 3, but allow for idiosyncratic technology shocks and a nondegenerate initial distribution of prices. We also rule out lump sum taxes. We consider taxes on consumption, investment, labor and capital income, and profits.

The production function of each good $i$, now, uses labor, $n_{i t}$, and capital, $k_{i t}$, according to

$$
c_{i t}+i_{i t}+g_{i t}=y_{i t}=A_{t} A_{i t} F\left(k_{i t}, n_{i t}\right)
$$

where $A_{i t}$ is a firm specific productivity shock that is i.i.d. across firms.

Let $\gamma_{i t} \in\{0,1\}$ be i.i.d random variables, such that, if $\gamma_{i t}=1$, the firm can revise the price. Marginal cost is now firm specific, $M C_{i}\left(U_{t}, W_{t}\right)=\frac{U_{t}}{A_{t} A_{i t} F_{k}(t)}=\frac{W_{t}}{A_{t} A_{i t} F_{n}(t)}$. The firms that are able to change prices choose the price $p_{i t}^{*}$ to maximize profits where output $y_{i t+j}$ must satisfy the technology constraint (69), and the demand function, obtained from (8), (9), and (27) where $Y_{t}=C_{t}+I_{t}+G_{t}$. The optimal price set by these firms is

$$
p_{i t}^{*}=\frac{\theta}{(\theta-1)} E_{t} \sum_{j=0}^{\infty} \eta_{t, j} \frac{W_{t+j}}{A_{t+j} A_{i t+j} F_{n}(t+j)},
$$

where the weights are given by (15). The price of firm $i$ is $p_{i t}=p_{i t}^{*}$ if $\gamma_{i t}=1$, and $p_{i t}=p_{i t-1}$, otherwise.

The present value budget constraint for the household as of period zero, with equality, is equation (64), where

$$
\Pi_{t}=\int_{0}^{1}\left(p_{i t}-\frac{W_{t}}{A_{t} A_{i t} F_{n}(t)}\right)\left(\frac{p_{i t}}{P_{t}}\right)^{-\theta} Y_{t} d i .
$$

Using the demand functions (9), (27) and (8), and (69), it follows that

$$
C_{t}+K_{t+1}-(1-\delta) K_{t}+G_{t}=\left[\int_{0}^{1}\left(\frac{p_{i t}}{P_{t}}\right)^{-\theta} A_{i t}^{-1} d i\right]^{-1} A_{t} F\left(N_{t}, K_{t}\right)
$$

In this economy production efficiency cannot be achieved. With idiosyncratic shocks, if prices were flexible, then firms would set

$$
p_{i t}=\frac{\theta}{\theta-1} \frac{W_{t}}{A_{t} A_{i t} F_{n}(t)} .
$$

\footnotetext{
${ }^{28}$ It is customary for many states in the US to announce yearly sales tax holidays for specific sets of goods. They typically last for only a few days.

${ }^{29}$ Commonly known as Cash for Clunkers, this was a temporary subsidy for the trading in and purchase of a new, more fuel efficient, vehicle. The initial budget was set to one billion dollars and planned to last for five months. Due to the high number of applications, it was terminated after the second month, and the final budget was close to three billion.

${ }^{30}$ The rate was reduced from $8 \%$ to $4 \%$ during the last four months of 2011 .
} 
The resource constraints would be written as

$$
C_{t}+K_{t+1}-(1-\delta) K_{t}+G_{t}=\left[\int_{0}^{1}\left(A_{i t}\right)^{\theta-1} d i\right]^{\frac{1}{\theta-1}} A_{t} F\left(N_{t}, K_{t}\right),
$$

to be compared with (72). With sticky prices, it is impossible to replicate the volatile pattern of relative prices needed to have production efficiency ${ }^{31}$.

Equilibria. An equilibrium for $\left\{C_{t}, L_{t}, N_{t}, K_{t}\right\},\left\{p_{i t}, p_{i t}^{*}, P_{t}, W_{t}, U_{t}\right\}$, and $\left\{i_{t}, \tau_{t}^{c}, \tau_{t}^{n}, \tau_{t}^{k}, s_{t}^{I}, \tau_{t}^{d}\right\}$ is characterized by the household marginal conditions (11), (13), with $i_{t} \geq 0$, (30), the firms marginal condition for the choice of factors (33), the price setting constraint (70), where $Y_{t}=C_{t}+K_{t+1}-(1-\delta) K_{t}+G_{t}$, the condition for the price level (7), the budget constraint (64), and, finally, the resource constraints $N_{t}=1-L_{t}$ and (72), with $p_{i t}=p_{i t}^{*}$ if $\gamma_{i t}=1$, and $p_{i t}=p_{i t-1}$, otherwise. If, at time zero, firm $i$ cannot optimally choose the price, because $\gamma_{i 0}=0$, then $p_{i 0}=p_{i,-1}$.

Circumventing the zero bound constraint. In order to show that the zero bound does not restrict the set of allocations, consider an allocation and a sequence of prices $\left\{p_{i t}, p_{i t}^{*}, P_{t}, W_{t}, U_{t}, C_{t}, L_{t}, N_{t}, K_{t}\right\}$ that satisfy the equilibrium conditions above, but do not necessarily satisfy the zero bound constraint. Let $\left\{i_{t}, \tau_{t}^{c}, \tau_{t}^{n}, \tau_{t}^{k}, s_{t}^{I}, \tau_{t}^{d}\right\}$ be a sequence of taxes and nominal interest rates that supports those prices and allocation. The same allocation and process for prices can be implemented with another sequence for taxes and interest rates $\left\{\tilde{\imath}_{t}, \tilde{\tau}_{t}^{c}, \tilde{\tau}_{t}^{n}, \tilde{\tau}_{t}^{k}, \widetilde{s}_{t}^{I}, \tilde{\tau}_{t}^{d}\right\}$, in such a way that the zero bound constraint is satisfied. We can construct consumption, profit, and labor and capital income taxes that implement the original allocation with the new interest rate $\tilde{\imath}_{t}=\max \left\{i_{t}, 0\right\}$ following the exact same steps as in Section 5 .

\section{References}

[1] Blanchard, O., G. Dell'Ariccia and P. Mauro, 2010, Rethinking Macroeconomic Policy, IMF Staff Position Note.

[2] Calvo, G., 1983, Staggered Prices in a Utility-Maximizing Framework, Journal of Monetary Economics 12: 383-398.

[3] Chari, V. V., L. Christiano and P. Kehoe, 1991, Optimal Fiscal and Monetary Policy: Some Recent Results. Journal of Money, Credit, and Banking 23 (August): 519-539.

[4] Christiano, L., M. Eichenbaum, and S. Rebelo, 2011, When is the Government Spending Multiplier Large? Journal of Political Economy 119 (1): 78-121.

[5] Correia, I., J. P. Nicolini and P. Teles, 2008, Optimal Fiscal and Monetary Policy: Equivalence Results, Journal of Political Economy 168 (1): 141-170.

\footnotetext{
${ }^{31}$ This volatility would require a richer set of instruments, i.e. consumption and labor taxes specific to each firm in the economy.
} 
[6] Diamond, P. A., and J. A. Mirrlees, 1971, Optimal Taxation and Public Production, American Economic Review 61: 8-27 and 261-68.

[7] De Long, J., and L. Summers, L.H., 1986, Is Increased Price Flexibility Stabilizing? American Economic Review 76: 1031-44.

[8] Drautzburg, T. and H. Uhlig, 2011, Fiscal Stimulus and Distortionary Taxation, NBER Working Papers 17111, National Bureau of Economic Research, Inc.

[9] Eggertsson, G. B., 2009, What Fiscal Policy is Effective at Zero Interest Rates?, mimeo, Federal Reserve Bank of New York.

[10] Eggertsson, G. B., and M. Woodford, 2003, The Zero Bound on Interest Rates and Optimal Monetary Policy, Brookings Papers on Economic Activity 1: 212-219.

[11] Eggertsson, G. B., and M. Woodford, 2004a, Policy Options in a Liquidity Trap, American Economic Review 94, 2: 76-79.

[12] Eggertsson, G. B., and M. Woodford, 2004b, Optimal Monetary and Fiscal Policy in a Liquidity Trap, ISOM conference volume.

[13] Feldstein, M, 2003, Rethinking Stabilization, Federal Reserve Bank of Kansas City.

[14] Krugman, P, 1998, It's Baack! Japan's Slump and the Return of the Liquidity Trap, Brookings Papers on Economic Activity 29, 2: 137-187.

[15] Lucas, R. E., Jr. and N. L. Stokey, 1983, Optimal Fiscal and Monetary Policy in an Economy without Capital, Journal of Monetary Economics 12, 1: 55-93.

[16] Mertens, K. and M. O. Ravn, 2010, Fiscal Policy in an Expectations Driven Liquidity Trap, CEPR Discussion Paper 7931.

[17] Romer, C. and J. Bernstein, 2009, The Job Impact of the American Recovery and Reinvestment Plan, Council of Economic Advisers.

[18] Werning, I., 2011, Managing a Liquidity Trap: Monetary and Fiscal Policy, mimeo, MIT.

[19] Woodford, M, 2010, Simple analytics of the government spending multiplier, mimeo, Columbia University.

[20] Yun, T., 2005, Optimal Monetary Policy with Relative Price Distortions, American Economic Review 95: 89-108. 

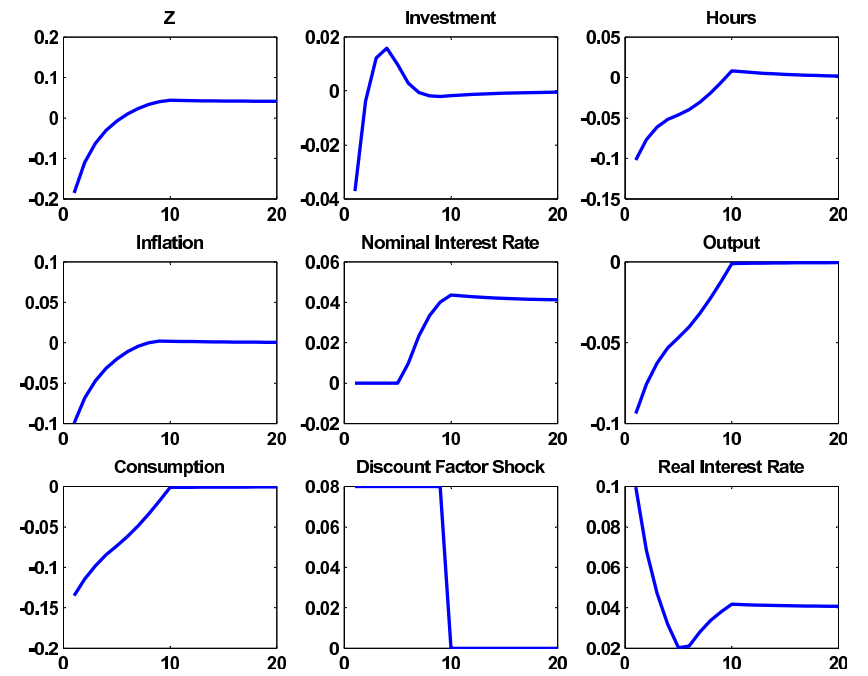

Figure 1: Dynamic path for the ECONomy, sticky PRICes, flexible Wages, Constant taXes. Time, measured in quarters, is on the horizontal axis. Investment, hours, output and consumption are measured in log-deviations from steady state. The nominal interest rate, the real interest rate, the target $Z$ in the Taylor rule, and inflation are measured in annualized levels.
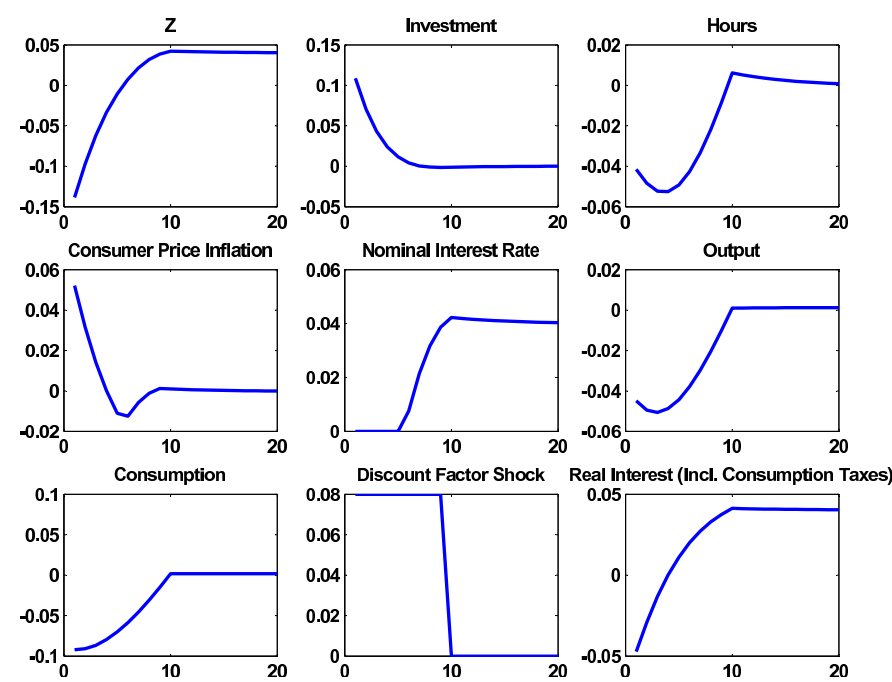

Figure 2: DyNAmic PATH FOR THE ECONOMY, STICKY PRICES, FLEXIBle WAGES, UNCONVENTIONAL TAXES. Time, measured in quarters, is on the horizontal axis. Investment, hours, output and consumption are measured in log-deviations from steady state. The nominal interest rate, the real interest rate, the target $Z$ in the Taylor rule, and inflation are measured in annualized levels. 

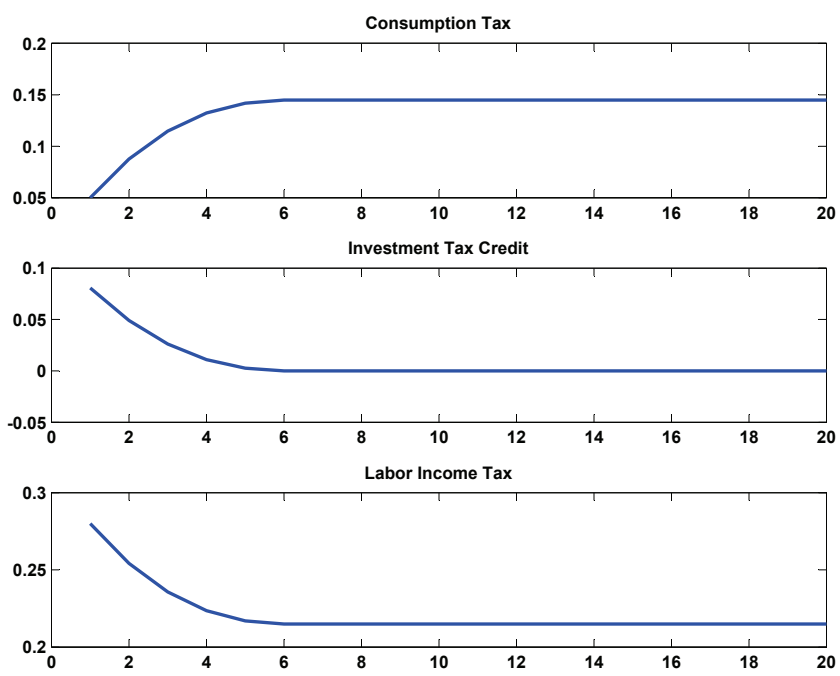

Figure 3: Dynamic path for unconventional taxes, sticky prices, flexible wages. Time, measured in quarters, is on the horizontal axis. Taxes are measured in levels.
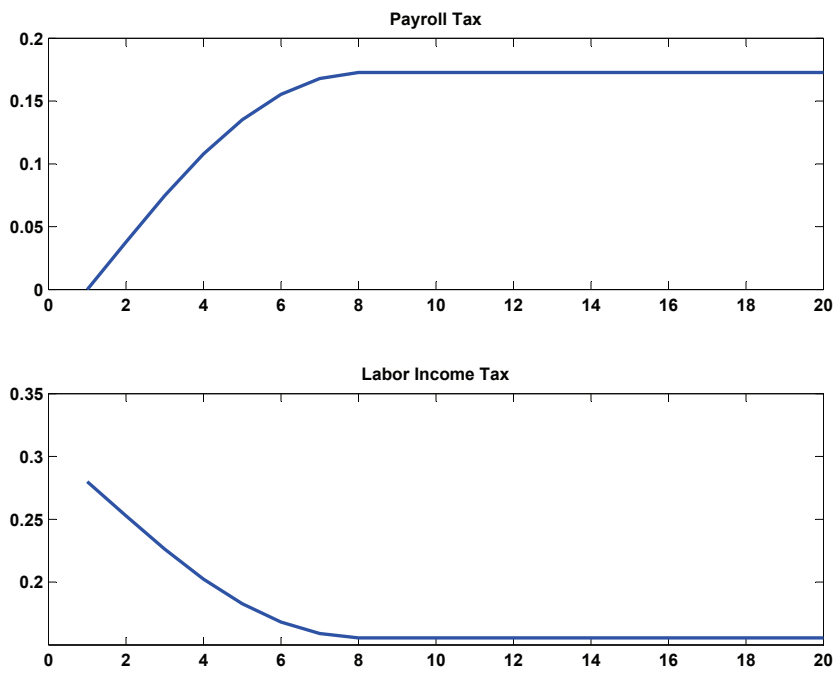

Figure 4: Dynamic Path For the alternative Set of unconventional taXes, flexible Prices, STICKY WAGES. Time, measured in quarters, is on the horizontal axis. Taxes are measured in levels. 

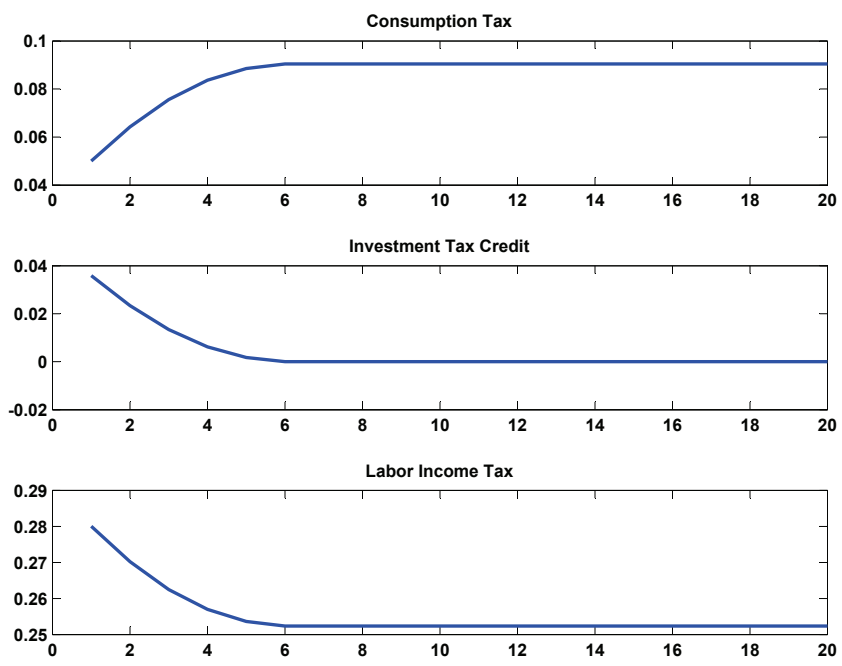

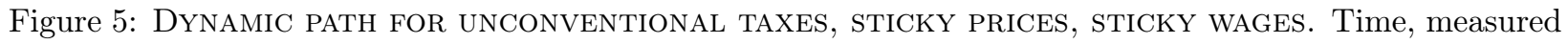
in quarters, is on the horizontal axis. Taxes are measured in levels.
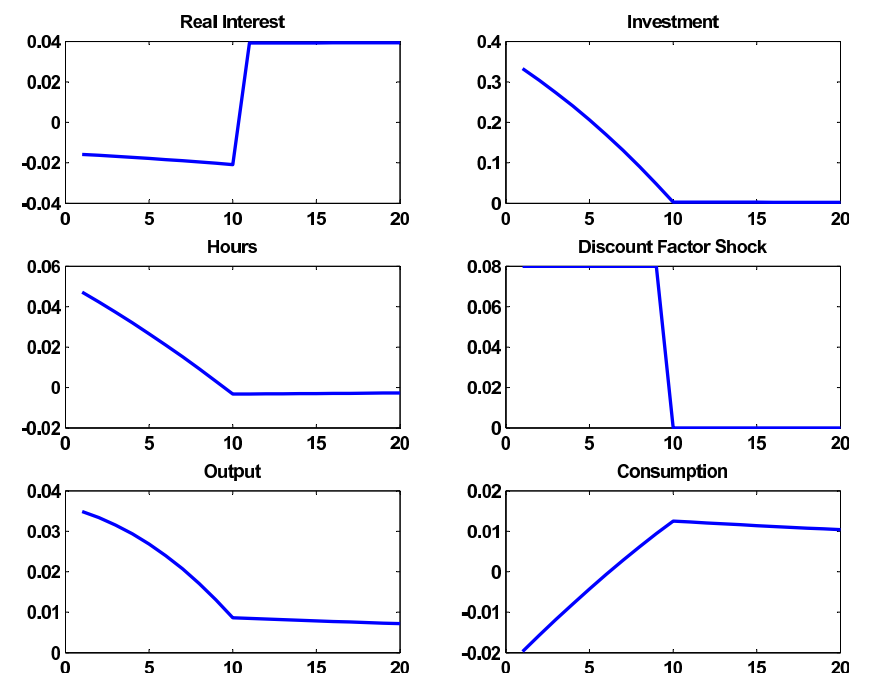

Figure 6: FleXible PRice allocation. Time, measured in quarters, is on the horizontal axis. Investment, hours, output and consumption are measured in log-deviations from steady state. The nominal interest rate, the real interest rate, the target $Z$ in the Taylor rule, and inflation are measured in annualized levels. 

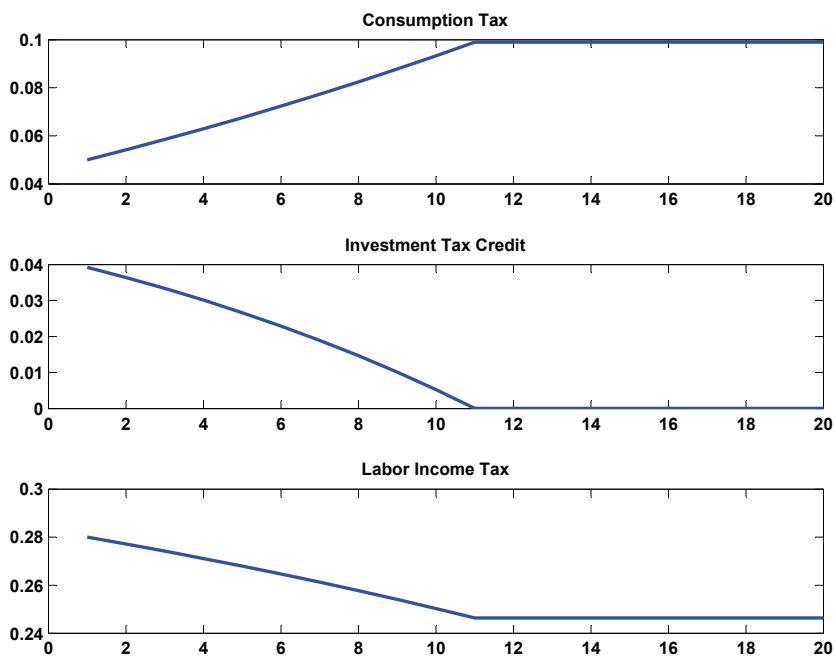

Figure 7: Dynamic Path for unconventional taxes to Replicate the FleXible PRICE, FleXible WAGE ALlOCATION: STICKY PRICES, FLEXIBle WAGES. Time, measured in quarters, is on the horizontal axis. Taxes are measured in levels.
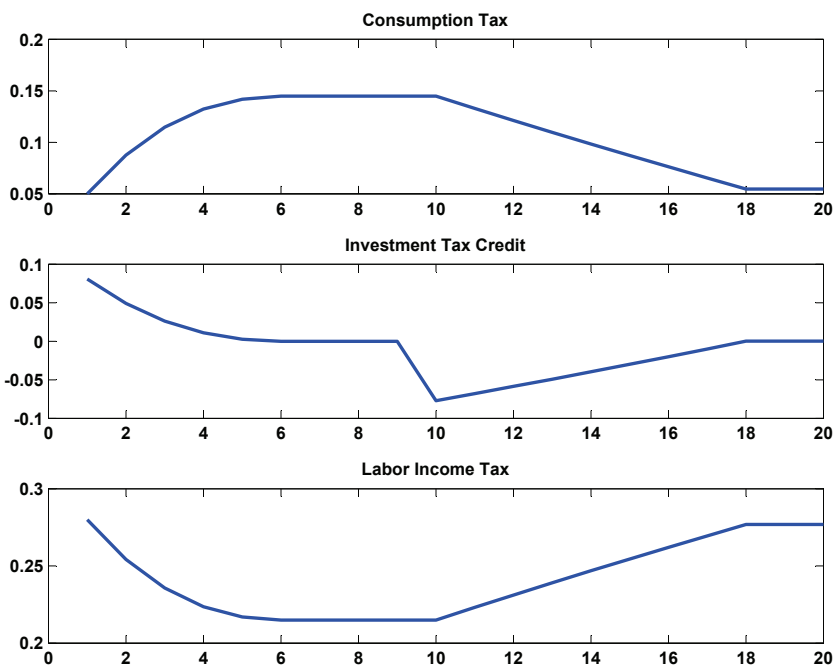

Figure 8: Building a BUfFER in GOOD times: DyNAmiC PATH FOR UnCONVENTIONAL TAXES, STICKY PRICES, FleXible WAges. Time, measured in quarters, is on the horizontal axis. Taxes are measured in levels. 


$\begin{array}{lrr} & T^{W}=10 & T^{W}=\infty \\ \text { Constant taxes, sticky prices, flexible wages } & 6.5 \% & 1.2 \% \\ \text { Unconventional taxes, sticky prices, flexible wages } & 4.3 \% & 0.8 \% \\ \text { Constant taxes, flexible prices, sticky wages } & 5.4 \% & 1.0 \% \\ \text { Unconventional taxes, flexible prices, sticky wages } & 1.1 \% & 0.2 \% \\ \text { Constant taxes, sticky prices, sticky wages } & 3.5 \% & 0.6 \% \\ \text { Unconventional taxes, sticky prices, sticky wages } & 2.5 \% & 0.4 \% \\ \text { Constant taxes, flexible prices, flexible wages } & -3.7 \% & -0.6 \%\end{array}$

Table 1: Welfare losses relative to steady state. Constant taxes vs. unconventional taxes. Different values of $T^{W}$ refer to different welfare metrics (proportional decrease of steady-state consumption for the first $T^{W}$ periods). 